\title{
The Benguela Upwelling System: Quantifying the Sensitivity to Resolution and Coastal Wind Representation in a Global Climate Model**
}

\author{
R. JUSTIN SMALL \\ Climate and Global Dynamics Division, National Center for Atmospheric Research, Boulder, Colorado \\ ENRIQUE CURCHITSER \\ Department of Environmental Sciences, Rutgers, The State University of New Jersey, New Brunswick, New Jersey \\ KATHERINE HEDSTROM \\ Institute of Marine Science, University of Alaska Fairbanks, Fairbanks, Alaska \\ BRIAN KAUFFMAN AND WILLIAM G. LARGE \\ Climate and Global Dynamics Division, National Center for Atmospheric Research, Boulder, Colorado
}

(Manuscript received 6 March 2015, in final form 7 August 2015)

\begin{abstract}
Of all the major coastal upwelling systems in the world's oceans, the Benguela, located off southwest Africa, is the one that climate models find hardest to simulate well. This paper investigates the sensitivity of upwelling processes, and of sea surface temperature (SST), in this region to resolution of the climate model and to the offshore wind structure. The Community Climate System Model (version 4) is used here, together with the Regional Ocean Modeling System. The main result is that a realistic wind stress curl at the eastern boundary, and a high-resolution ocean model, are required to well simulate the Benguela upwelling system. When the wind stress curl is too broad (as with a $1^{\circ}$ atmosphere model or coarser), a Sverdrup balance prevails at the eastern boundary, implying southward ocean transport extending as far as $30^{\circ} \mathrm{S}$ and warm advection. Higher atmosphere resolution, up to $0.5^{\circ}$, does bring the atmospheric jet closer to the coast, but there can be too strong a wind stress curl. The most realistic representation of the upwelling system is found by adjusting the $0.5^{\circ}$ atmosphere model wind structure near the coast toward observations, while using an eddy-resolving ocean model. A similar adjustment applied to a $1^{\circ}$ ocean model did not show such improvement. Finally, the remote equatorial Atlantic response to restoring SST in a broad region offshore of Benguela is substantial; however, there is not a large response to correcting SST in the narrow coastal upwelling zone alone.
\end{abstract}

\section{Introduction}

\section{a. Eastern boundary SST bias}

Common biases seen in the current and previous generation of climate models include the representation of

\footnotetext{
* Supplemental information related to this paper is available at the Journals Online website: http://dx.doi.org/10.1175/JCLI-D-150192.s1.

Corresponding author address: R. Justin Small, National Center for Atmospheric Research, 1850 Table Mesa Drive, Boulder, CO 80305.

E-mail: jsmall@ucar.edu
}

climatological mean sea surface temperature (SST) in the equatorial region and at eastern boundaries (Mechoso et al. 1995; Davey et al. 2002; Richter and Xie 2008; Richter et al. 2012; Mechoso et al. 2014; Richter 2015). These mean state biases can affect the climate variability, such as in the equatorial Pacific [influence on El NiñoSouthern Oscillation (ENSO); Meehl et al. 2001], and the zonal mode in the southeast Atlantic (Richter et al. 2014; Ding et al 2015). Biases of SST near the equator have a large influence on the intertropical convergence zone (ITCZ; Large and Danabasoglu 2006, hereafter LD06), which may in turn lead to further equatorial SST bias via modification of the easterlies, with the possibility of a coupled feedback (Richter et al. 2014). 
(a)

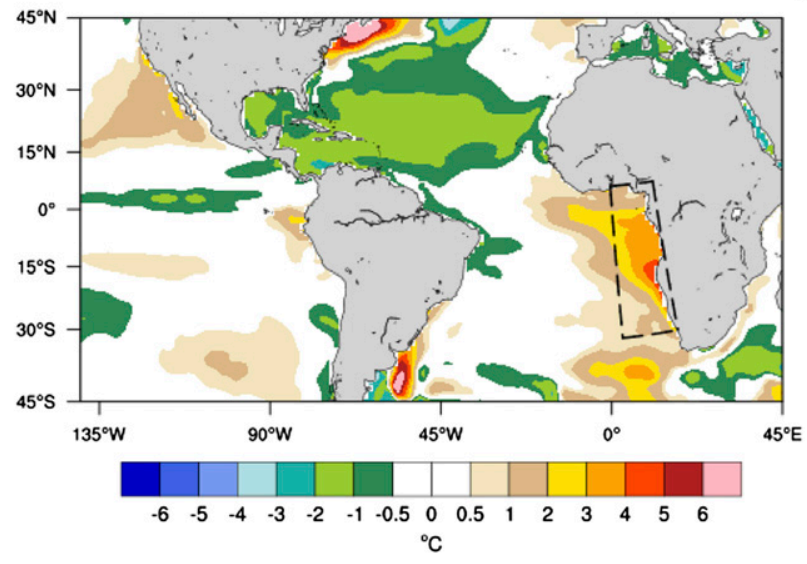

(b)

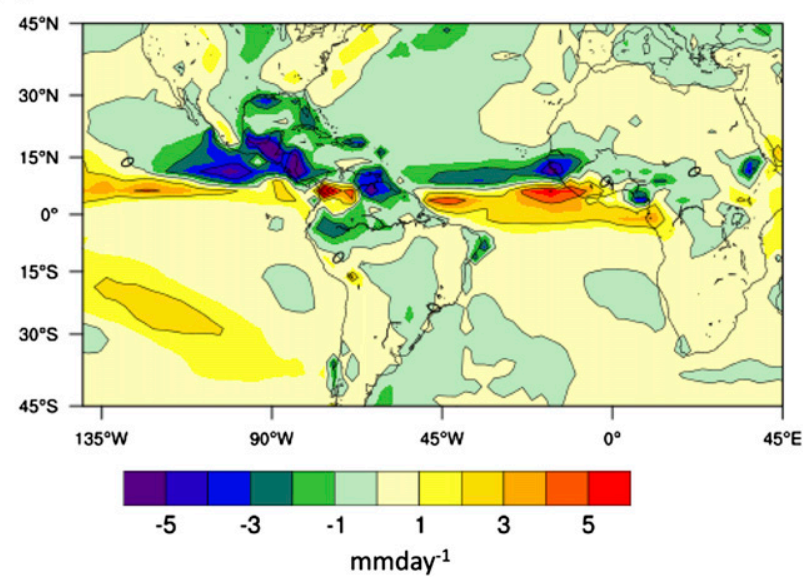

FIG. 1. (a) Bias of SST in JJA in CCSM4-0.5 , relative to the HadISST dataset averaged from 1870 to 1899 . (b) Bias of precipitation in JJA in CCSM4-0.5 $5^{\circ}$, relative to the Global Precipitation Climatology Project data (Huffman et al. 1997). In (a) the ROMS domain is marked with a dashed line.

Improvements to some of these biases have recently been obtained. For example, eastern boundary SST bias in the North Pacific and South Pacific was lessened when ocean and atmosphere grid spacing were concurrently reduced in McClean et al. (2011) and Delworth et al. (2012), while Gent et al. (2010) achieved some improvement by changing atmospheric model resolution alone. Despite these advances, South Atlantic eastern boundary SST remains stubbornly hard to fix; for example, Gent et al. (2010, their Fig. 3) only reduced the maximum warm SST error in this region from $7^{\circ} \mathrm{C}$ in the annual mean with $2^{\circ}$ atmosphere grid spacing to a still excessive $5^{\circ} \mathrm{C}$ with $0.5^{\circ}$ grid spacing (Fig. 1a shows similar results for June-August, from the CCSM4-0.5 $5^{\circ}$ run described in section 2).

This paper focuses on the South Atlantic eastern boundary system, where climate model SST errors are typically the largest among eastern boundary regions [see Fig. 1 of Wang et al. (2014)]. It is here that the southward flowing Angola Current and northward Benguela Current meet (between $15^{\circ}$ and $20^{\circ} \mathrm{S}$ ) in an area often referred to as the Angola Benguela Front or ABF (Fig. 2a), and it is hypothesized that incorrect location of the front as well as deficiencies in upwelling lead to a local maximum of SST bias (Grodsky et al. 2012; Xu et al. 2014a). On the eastern edge of the South Atlantic subtropical anticyclone, land-sea thermal contrast and the orography drive strong winds alongshore (Nicholson 2010) with a peak magnitude close to the Namibia coast (Fig. 2b), leading to local features such as the Lüderitz and Cunene upwelling cells.

It has been hypothesized that errors in the wind, SST, and thermocline structure in the equatorial Atlantic affect the Benguela upwelling zone, for example via propagation of equatorial and coastal Kelvin waves (Wahl et al. 2011; Richter et al. 2012; Xu et al. 2014b; Toniazzo and Woolnough 2014; Voldoire et al. 2014). The two regions may also interact in the opposite direction: LD06 restored southeastern boundary temperature and salinity structure in the Atlantic in CCSM3 toward observations, in a region extending from $30^{\circ} \mathrm{S}$ to the equator and $9^{\circ} \mathrm{E}$ to the West African coast, and found that this also reduced SST and precipitation biases in the central equatorial Atlantic (Fig. 1b shows the precipitation bias in the model CCSM $4-0.5^{\circ}$ ). The current paper was motivated by the work of LD06 and the suggestion that coastal upwelling, in addition to low stratocumulus clouds (Mechoso et al. 1995; Ma et al. 1996; Wahl et al. 2011; Voldoire et al. 2014), is involved in eastern boundary SST bias, with substantial remote effects.

\section{b. Coastal upwelling and currents}

Upwelling and coastal currents are very sensitive to the precise structure of the wind stress near the coast. For eastern boundary systems, when the nearshore wind stress is strong and parallel to the coast in a generally equatorward direction, the Ekman divergence of surface water leads to offshore transport and coastal upwelling. In addition, downwind currents are generated in response to alongshore coastal winds (Charney 1955; Yoshida 1955; Philander and Yoon 1982). In contrast, when the strongest winds are located offshore, with a consequent wind stress curl (WSC) associated with wind weakening toward the coast, it leads to Ekman pumping-driven upwelling (Enriquez and Friehe 1995; Pickett and Paduan 2003). 

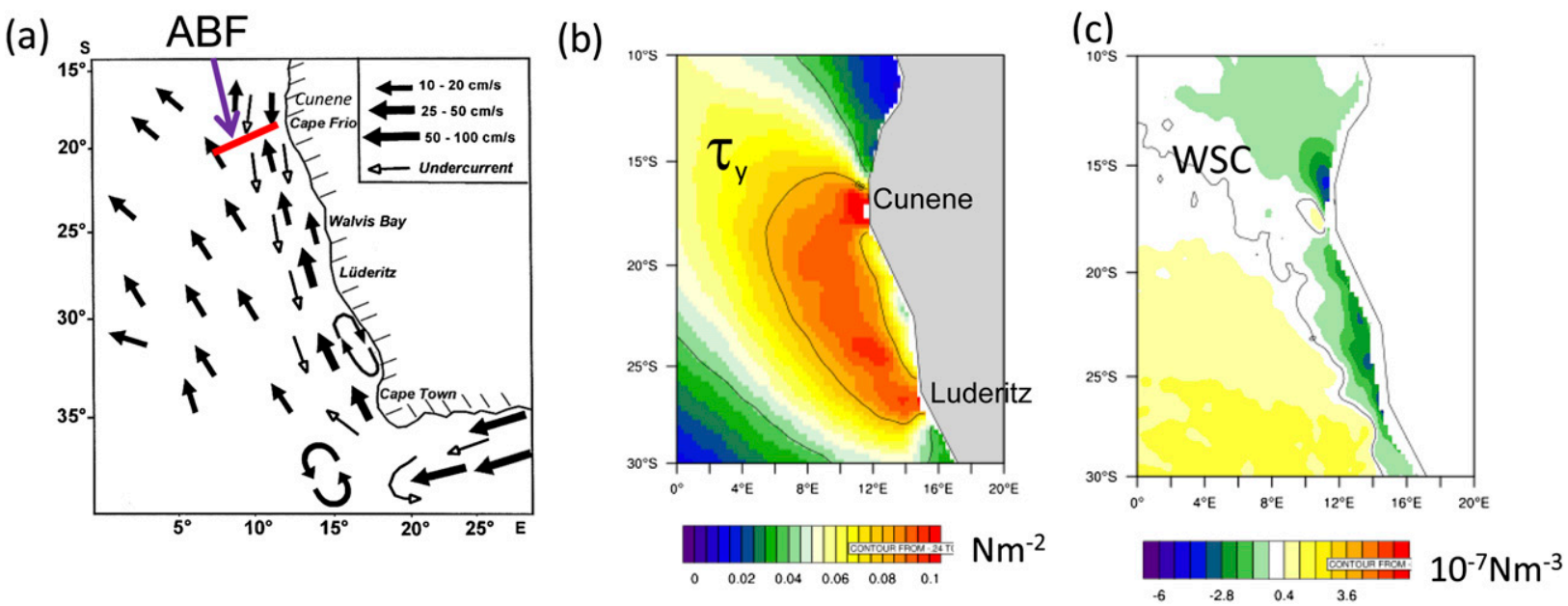

FIG. 2. (a) After Fennel (1999), a schematic of the surface flow and undercurrent in the Benguela region. ABF marks the Angola/ Benguela front. Reproduced with permission of the American Meteorological Society. (b) Meridional component of wind stress from QuikSCAT, JJA climatology. For this and subsequent plots, QuikSCAT data are from the Risien and Chelton (2008) product. (c) The corresponding wind stress curl in JJA from QuikSCAT. The locations of the prominent Lüderitz and Cunene upwelling cells are marked on (a) and (b), and additionally Cape Frio on (a).

The relevance of the WSC structure to eastern boundary currents has been treated theoretically in the linear models of McCreary and Chao (1985) and McCreary et al. (1987), focusing on the California Current system, and of Fennel et al. (2012) and Junker (2014), focused on the Benguela system. Both of these theories demonstrate that when the alongshore atmospheric jet core is sufficiently far away from the coast (and hence the WSC structure is broad in the zonal direction), the solution is governed by an approximate Sverdrup balance, somewhat modified by mixing, with deep, poleward currents at the boundary. In contrast, for a more inshore location of the atmospheric jet, leading to upwelling-favorable conditions, a downwind coastal jet forms in the upper ocean, with an underlying counterflow following the passage of Kelvin waves.

The Fennel et al. (2012) and Junker (2014) approach allows for a separation of solutions into a "WSC driven" part and a "coastal wind stress driven" part. The response to strong coastal wind stress occurs on the horizontal scale of the ocean internal Rossby radius, while the response to the WSC forcing occurs on the scale of the wind stress change. A number of studies have confirmed the strong sensitivity of upwelling to the structure of the WSC in regional ocean models (Capet et al. 2004; Song et al. 2011; Renault et al. 2012; Desbiolles et al. 2014).

The observed WSC off the Benguela in June-August (JJA) is shown in Fig. 2c-the band of negative WSC near the coast leads to Ekman pumping (upward vertical velocity) in the Southern Hemisphere. Thus the Benguela upwelling will have contributions due to strong alongshore wind stress, particularly at the Lüderitz and Cunene cells (Fig. 2b), and also due to the WSC. In this paper we will also examine which of these processes dominates in particular model simulations.

\section{c. Aims}

The aim of this paper is to determine how a global climate model representation of upwelling and coastal currents affects the deficiencies of SST simulation in the Benguela upwelling region. To achieve this aim, we use an approach including both a global climate model and a regional ocean model. Specifically the Regional Ocean Modeling System (ROMS) is embedded in the Community Climate System Model (CCSM4) to investigate sensitivity to atmosphere and ocean resolution and also to the structure of wind stress forcing near the coast.

The paper is structured as follows. Section 2 presents the models, observed datasets, and experiments. Section 3 shows and explains the sensitivity of Benguela SST to resolution of the climate model, focusing on the consequences of Sverdrup balance. Section 4 presents sensitivity tests with coastal wind stress modified to better match observations. The remote equatorial Atlantic response to fixing biases in temperature and salinity off the Benguela is discussed in section 5. This is followed by a discussion of the applicability of Sverdrup balance to the observed Benguela system and of the resolution required to best describe coastal upwelling. Finally, conclusions are drawn. 


\section{Models and data}

\section{a. CCSM4}

The main modeling system and coupling framework is CCSM4 (Gent et al. 2011). CCSM4 comprises the Community Atmosphere Model version 4 (CAM4; Neale et al. 2013), Community Land Model version 3.5 (CLM3.5; Oleson et al. 2008), Community Ice Code version 4 (Hunke and Lipscomb 2008), and the Parallel Ocean Program version 2 (POP2; Smith et al. 2010; Danabasoglu et al. 2012). CAM4 uses the finite-volume dynamical core and is discretized on a regular longitudelatitude grid, and has 26 hybrid pressure levels in the vertical. CLM3.5 runs on the same horizontal grid as CAM. POP2 is on a nominal $1^{\circ}$ grid (actually $1.11^{\circ}$ in the zonal direction and meridionally between $0.27^{\circ}$ at the equator and $0.54^{\circ}$ at higher latitudes). It has 60 vertical levels, with $10-\mathrm{m}$ grid spacing in upper $100 \mathrm{~m}$. Air-sea fluxes are computed in the coupler with the Large and Yeager (2009) scheme. The ocean model communicates with the coupler once per day, while the atmosphere receives updated fluxes every $30 \mathrm{~min}$. More details of the CCSM4 components can be found in Gent et al. (2011).

In this paper the sensitivity of CCSM4 to atmospheric resolution is explored, in the range of $2^{\circ}-0.5^{\circ}$, and details are given in section $2 \mathrm{~d}$. The ocean model resolution remains unchanged in the CCSM4 experiments.

\section{b. $R O M S$}

The ocean model ROMS (Shchepetkin and McWilliams 2005) is a free-surface terrain-following coordinate ocean model employing split-explicit time stepping. ROMS has been configured for the southeast Atlantic (the horizontal domain is shown in Fig. 1a as a dashed line), where two of the boundaries are open and use the Marchesiello et al. (2001) schemes. There is no explicit horizontal viscosity except in sponge layers near the open boundaries. As with POP2, ROMS employs the Large et al. (1994) boundary layer vertical mixing scheme. The horizontal grid spacing is $7 \mathrm{~km}$, and there are 60 vertical levels that are refined near the bathymetry and near the free surface to give better vertical resolution in the surface and boundary layer. (For reference, in typical sections off the Benguela shelf, there are at least 13 levels in the top $100 \mathrm{~m}$.)

Further details of ROMS applications to eastern boundaries can be found in Shchepetkin and McWilliams (2005), Penven et al. (2005), Marchesiello et al. (2003), Capet et al. (2008), Veitch et al. (2009), and Colas et al. (2013).

\section{c. The nested regional climate model}

For downscaling of information, ROMS receives nearsurface atmospheric variables from CAM and lateral ocean boundary information from POP. The atmospheric variables are received every 30 minutes, which, together with the ROMS SST, are passed to a ROMS air-sea flux routine which is a replica of that used in CCSM4. The ocean boundary conditions are daily averaged POP fields, interpolated onto the ROMS vertical levels.

In addition to allowing downscaling, the nested regional climate model (nRCM) allows "upscaling" to the global domain by two methods. First the ROMS SST is merged with the POP SST, and then passed to the CCSM4 coupler, where it interacts with the other global model components in the standard way. We refer to the merged SST as a composite SST. Second, the POP temperature and salinity is restored to that of ROMS over the ROMS domain, to a depth of $1000 \mathrm{~m}$. The restoring is quite strong (10-day time scale) and ensures that the global ocean model solution is consistent with ROMS and also with the composite SST that is used to compute air-sea fluxes.

\section{d. Model experiments}

Experiments have been performed with CCSM4, and then with CCSM4 coupled to ROMS (nRCM). An abbreviated list is given in Table 1 .

\section{1) CCSM4 EXPERIMENTS}

(i) CCSM4-0.5 . Here CAM4 has a horizontal grid spacing of $0.63^{\circ} \times 0.47^{\circ}$. For the CCSM4-0.5 ${ }^{\circ}$ experiments, we ran a 150 -yr simulation with preindustrial greenhouse gas concentrations (an "1850 run") initialized from year 200 of a preexisting simulation (C. Shields 2014, personal communication).

(ii) CCSM4-1 $1^{\circ}$. This is the standard-resolution CCSM4, with CAM4 on a $1.25^{\circ} \times 0.9^{\circ}$ grid, described in Gent et al. (2011). We use the "long baseline" (1300 yr) $\mathrm{CCSM} 4^{\circ}-1^{\circ}$ run, with constant preindustrial year 1850 forcings, as documented in Gent et al. (2011).

(iii) CCSM4-2 $2^{\circ}$ As a reference simulation at coarse resolution, we also use data from the CCSM3.5 twentieth-century simulation with $1.9 \times 2.5^{\circ}$ atmosphere grid described by Gent et al. (2010) and refer to this, for convenience, as CCSM4-2 .

(iv) CCSM4-MOD. This is a wind stress sensitivity experiment based on CCSM4-0.5 but with an adjustment done to atmospheric wind data being passed to the ocean model off the Namibia/South Africa coast. (The method is similar to that described in section 4a.) The experiment was run for 20 years.

(v) Restoring experiments. Fifty-year simulations have been performed with CCSM $4-0.5^{\circ}$ where the ocean temperature and salinity are restored to monthly 
TABLE 1. List of experiments, showing the model system, component resolutions, and a brief description.

\begin{tabular}{|c|c|c|c|c|c|}
\hline $\begin{array}{l}\text { Experiment } \\
\text { name }\end{array}$ & $\begin{array}{l}\text { Model } \\
\text { system }\end{array}$ & Ocean grid spacing & $\begin{array}{l}\text { Atmosphere } \\
\text { grid spacing }\end{array}$ & $\begin{array}{c}\text { No. } \\
\text { of years }\end{array}$ & Brief description \\
\hline $\mathrm{CCSM} 4-2^{\circ}$ & CCSM3.5 & Nominal $1^{\circ}$ (see text) & $2^{\circ}$ & 30 (1970-99) & Twentieth century run with CCSM3.5 \\
\hline $\mathrm{CCSM} 4-1^{\circ}$ & CCSM4 & Nominal $1^{\circ}$ (see text) & $1^{\circ}$ & 1300 & 1850 condition long "baseline" \\
\hline CCSM4-0.5 & CCSM4 & Nominal $1^{\circ}$ (see text) & $0.5^{\circ}$ & 150 & 1850 conditions \\
\hline $\begin{array}{l}\text { LARGE } \\
\text { RESTORE }\end{array}$ & CCSM4 & Nominal $1^{\circ}$ (see text) & $0.5^{\circ}$ & 50 & $\begin{array}{l}\text { As CCSM } 4-0.5^{\circ} \text {, but ocean temperature } \\
\text { and salinity restored to Levitus, off } \\
\text { West Africa from Gulf of Guinea to } \\
29^{\circ} \mathrm{S} \text { and to } 1^{\circ} \mathrm{E}\end{array}$ \\
\hline $\begin{array}{l}\text { SMALL } \\
\text { RESTORE }\end{array}$ & CCSM4 & Nominal $1^{\circ}$ (see text) & $0.5^{\circ}$ & 50 & $\begin{array}{l}\text { As CCSM4-0.5 } \text {, but ocean temperature } \\
\text { and salinity restored to Levitus, off } \\
\text { West Africa from } 10^{\circ} \text { to } 29^{\circ} \mathrm{S} \text { and to } 8^{\circ} \mathrm{E} \text {. }\end{array}$ \\
\hline CCSM4-MOD & CCSM4 & Nominal $1^{\circ}($ see text $)$ & $0.5^{\circ}$ & 20 & $\begin{array}{l}\text { As CCSM } 4-0.5^{\circ} \text {, but wind vectors off } \\
\text { southeast Africa "shifted" by } 1^{\circ} \text { for } \\
\text { POP (see text) }\end{array}$ \\
\hline $\mathrm{nRCM}-1^{\circ}$ & $\mathrm{nRCM}$ & $\begin{array}{l}\text { 7-km ROMS in POP } \\
\text { nominal } 1^{\circ} \text { (see } \\
\text { text) }\end{array}$ & $1^{\circ}$ & 80 & $\begin{array}{l}1850 \text { condition with ROMS embedded in } \\
\text { CCSM } 4-1^{\circ}\end{array}$ \\
\hline $\mathrm{nRCM}-0.5^{\circ}$ & $\mathrm{nRCM}$ & $\begin{array}{l}\text { 7-km ROMS in POP } \\
\text { nominal } 1^{\circ} \text { (see } \\
\text { text) }\end{array}$ & $0.5^{\circ}$ & 50 & $\begin{array}{l}1850 \text { condition with ROMS embedded in } \\
\text { CCSM } 4-0.5^{\circ}\end{array}$ \\
\hline nRCM-MOD & $\mathrm{nRCM}$ & $\begin{array}{l}\text { 7-km ROMS in POP } \\
\text { nominal } 1^{\circ} \text { (see } \\
\text { text) }\end{array}$ & $0.5^{\circ}$ & 150 & $\begin{array}{l}\text { As nRCM-0.5 } \text {, but with wind vectors off } \\
\text { southeast Africa "shifted" by } 1^{\circ} \text { for } \\
\text { ROMS (see text) }\end{array}$ \\
\hline
\end{tabular}

climatology of the Levitus et al. (1998) World Ocean Atlas database in a narrow strip at the southeast Atlantic boundary, to 1000-m depth and with a restoring time scale of 10 days. The LARGE domain restored from the Gulf of Guinea south to $29^{\circ} \mathrm{S}$, and offshore to $1^{\circ} \mathrm{E}$, while the SMALL domain restored from $10^{\circ}$ to $29^{\circ} \mathrm{S}$, and offshore to $8^{\circ} \mathrm{E}$.

\section{2) NRCM EXPERIMENTS}

Two nRCM control simulations, one each for atmosphere resolutions of $1^{\circ}$ and $0.5^{\circ}$ respectively, and a sensitivity experiment were performed.

(i) $\mathrm{nRCM}-1^{\circ}$. ROMS is embedded within CCSM4-1 $1^{\circ}$ for an 80 -yr simulation. This was branched off year 863 of the CCSM $4-1^{\circ}$ run.

(ii) $\mathrm{nRCM}-0.5^{\circ}$. This includes ROMS in CCSM4-0.5 and was integrated for 50 years. It was initialized at the same point as the CCSM4-0.5 $5^{\circ}$ experiment.

(iii) nRCM-MOD. This is a wind stress sensitivity experiment based on $\mathrm{nRCM}-0.5^{\circ}$ but it has an adjustment done to the location of atmospheric wind data being passed to ROMS off the southeast Atlantic coast. Full details are given in section $4 \mathrm{a}$. The experiment was run for 150 years, initialized in same way as $\mathrm{nRCM}-0.5^{\circ}$.

\section{e. Observational data}

We make use of the HadISST dataset (Hurrell et al. 2008) for climatology of SST in the preindustrial era.
For detailed evaluation of the coastal zone the NOAA $0.25^{\circ}$ Optimum Interpolation SST (OISST; Reynolds et al. 2007; Banzon et al. 2014) is used. The Risien and Chelton (2008) QuikSCAT climatology is used for wind stress.

\section{Sensitivity of the Benguela upwelling system to model resolution}

Model solutions of CCSM4 and nRCM are compared here at different component resolutions. After discussing the role of atmosphere resolution in sections $3 \mathrm{a}$ and $3 \mathrm{~b}$, section $3 \mathrm{c}$ investigates the importance of ocean resolution. The ocean response to wind forcing is addressed in terms of the Sverdrup balance and Ekman pumping quantities. The latter is frequently used when discussing coastal upwelling systems (e.g., Pickett and Paduan 2003); however, whereas many papers have addressed whether Sverdrup balance holds in the ocean (e.g., Wunsch 2011 and references therein), their focus has not been on eastern boundaries.

\section{a. Sensitivity to atmosphere resolution, and the role of Sverdrup balance}

The eastern boundary currents in the CCSM4 simulations are best understood by analyzing the applicability of Sverdrup balance in those regions. Under Sverdrup balance, to leading order, the depth-integrated vorticity equation is governed by a balance between the 
linear advection term and the wind stress source term, such that

$$
\beta \rho_{0} \int_{-H}^{0} v d z=\nabla \times \tau
$$

where $\beta$ is the meridional gradient of the Coriolis parameter, $\rho_{0}$ is a reference ocean density, $v$ is the meridional current, $\tau$ the wind stress, and $H$ is the depth of the active ocean layer under consideration.

The only complexity in computing Eq. (1) is determination of the integration depth $H$. For the full geostrophic vorticity equation $H$ should be the bottom of the water column. But as explained by Marchesiello et al. (2003) and Wunsch (2011), evaluation of Sverdrup balance only needs integration to a depth where $w=0$, and it helps to avoid abyssal currents not likely to be governed by WSC. Marchesiello et al. (2003) and Wunsch (2011) use depths between 1000 and $1500 \mathrm{~m}$. Our interest is in currents that might affect the SST so we choose a fairly shallow depth of $500 \mathrm{~m}$. Tests with other integrating depths $(H)$ showed that shallower depths did not fully show the response to WSC while there was little change to the response at eastern boundaries when larger values of $H$ were considered.

The two terms of Eq. (1) are shown in Fig. 3 for the annual mean in the eastern Pacific and Atlantic equatorward of $45^{\circ}$ latitude, which includes the four major upwelling regions of the California Current, northwest Africa, Peru/Chile, and Benguela. As noted in many previous papers (Thomas et al. 2014; Gray and Riser 2014; Wunsch 2011), the balance clearly does not hold in western boundary currents and the Southern Ocean. However, in the subtropical gyres and eastern boundaries the match is very good in CCSM4 with a coarseresolution $2^{\circ}$ atmosphere model (Figs. 3a,b). The broad negative (positive) WSC at the far eastern boundary in the Southern (Northern) Hemisphere is matched by poleward transport there (boxed regions in Figs. 3a,b).

When the atmosphere is at $1^{\circ}$, the picture is similar (Figs. 3c,d), again with poleward dominating flow at the eastern boundary, but somewhat narrower than with $2^{\circ}$ atmosphere. For an atmosphere resolution of $0.5^{\circ}$, the WSC bands at the eastern boundaries get narrower still, and weaker in amplitude (Figs. 3e,f). The difference between CCSM4-0.5 $5^{\circ}$ and CCSM4- $2^{\circ}$ depth integrated meridional current (Fig. 3g) highlights the more equatorward flow in the higher-resolution simulation at the eastern boundaries. Note further that the WSC in the atmosphere model at $0.5^{\circ}$ (Fig. 3f) looks much closer to QuikSCAT observations (Fig. 3h) than WSC at $2^{\circ}$ or $1^{\circ}$, especially at the eastern boundaries. The same holds true even when the $0.25^{\circ}$ QuikSCAT data is subsampled to the coarser model grids of $2^{\circ}$ or $1^{\circ}$ (not shown).

The bands of WSC at the eastern boundaries are dominated by the $\partial \tau_{y} / \partial x$ term, where $\tau_{y}$ is the meridional component of wind stress, due to a horizontal shear between an offshore located wind jet and weaker winds at the coast. A rough estimate of the shear is $\Delta \tau / L$, where $\Delta \tau$ is the wind stress difference between the jet and coast and $L$ is the offshore distance to the core of the strongest winds or wind stress. Table 2 shows the distance $L$ for the northern (Cape Frio/Cunene) and southern (Lüderitz) upwelling regions of our interest in model simulations and the Risien and Chelton (2008) QuikSCAT climatology. In CCSM $4, L$ is approximately 3 to 4 times the atmosphere grid spacing, and thus reduces from $6^{\circ}$ to $8^{\circ}$ of longitude for CCSM $4-2^{\circ}$ to $2^{\circ}$ of longitude for CCSM4-0.5 $5^{\circ}$, which is still long compared to $L=0.25^{\circ}$ for QuikSCAT.

Further, the coarse-resolution simulations have weaker wind stress at the coast, as seen from Table $3: 0.03 \mathrm{~N} \mathrm{~m}^{-2}$ or less for CCSM4- $2^{\circ}$ compared to $0.09-0.1 \mathrm{~N} \mathrm{~m}^{-2}$ for CCSM4- $0.5^{\circ}$. In contrast the strength of the core of the jet (Table 4 ) is only slightly lower in CCSM $4-2^{\circ}$ $\left(0.07-0.08 \mathrm{~N} \mathrm{~m}^{-2}\right)$ compared to CCSM4-0.5 $(0.095-$ $0.105 \mathrm{~N} \mathrm{~m}^{-2}$ ).

\section{b. Implications for Benguela SST}

Grodsky et al. (2012) noted that the eastern boundary alongshore currents were southward in the Benguela zone in CCSM4 $-1^{\circ}$, opposite to the coastal jet direction expected from coastal upwelling (Philander and Yoon 1982) and from regional ocean simulations (Fennel et al. 2012). Further, Xu et al. (2014a) found a correlation between the SST bias and the location of the ABF, indicating that the relative extent of the southward Angola current and northward Benguela current affects SST. Thus the presence or otherwise of the dominant southward transport noted in section 3a should be important to the SST bias.

A close-up of the Sverdrup balance terms for CCSM $4-1^{\circ}$ and CCSM $4-0.5^{\circ}$ in the Benguela region is shown in Fig. 4, but now for the season of JJA when biases are largest (Grodsky et al. 2012). The vertical integral of the meridional velocity (multiplied by $\beta \rho_{0}$ ) is similar in spatial structure but weaker in amplitude to (and less broad than) the WSC in CCSM4-1 $1^{\circ}$ (Figs. 4a, b), both implying southward transport. The same does not hold for CCSM4- $0.5^{\circ}$, where the WSC is still negative, but the currents do not match the WSC south of Cape Frio and are mostly northward (Figs. 4d,e). This suggests that the fit of Sverdrup balance to the model results is closest when the resolved scales are large [e.g., in CCSM4 $-1^{\circ}$ (Figs. 4a,b) or CCSM4-2 $2^{\circ}$ and is a poor approximation when the scales are small (CCSM4-0.5 ; 
(a)

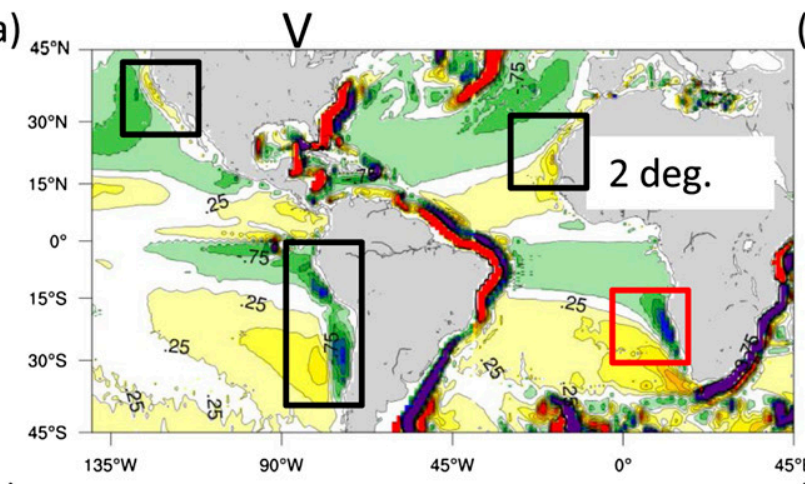

(c)

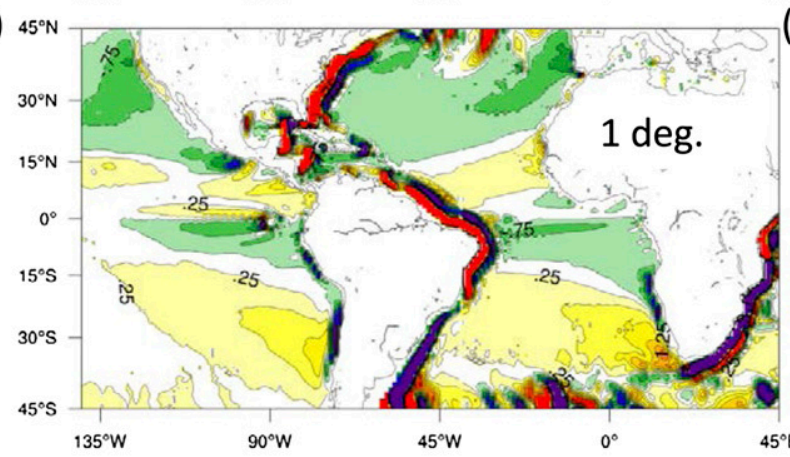

(b)

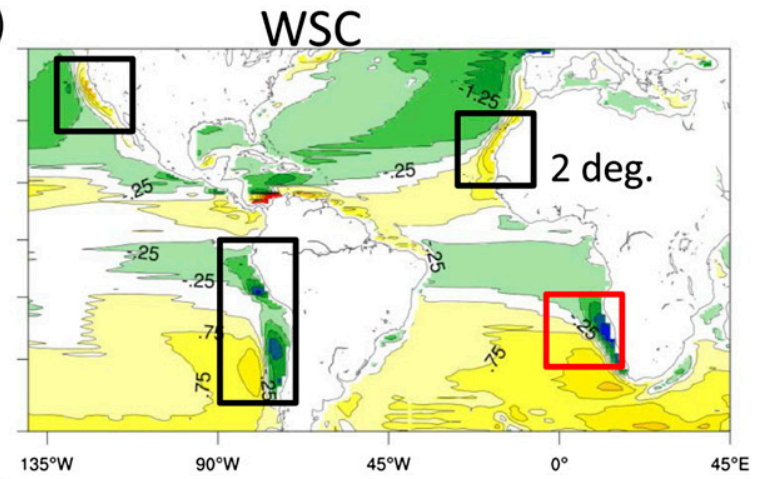

(d)

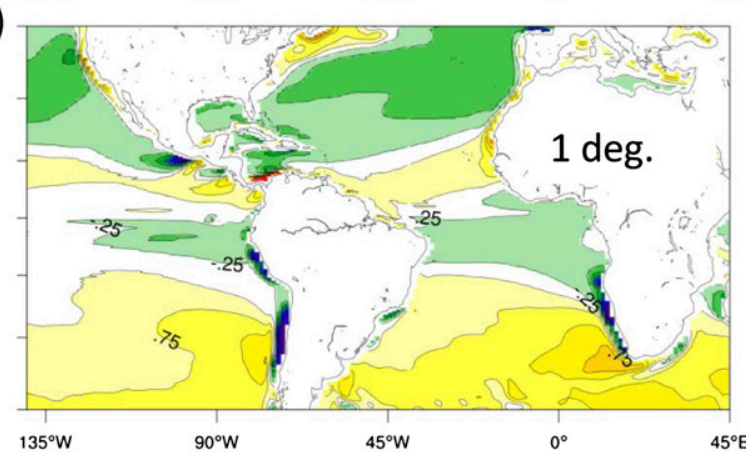

(e) $45^{\circ} \mathrm{N}$

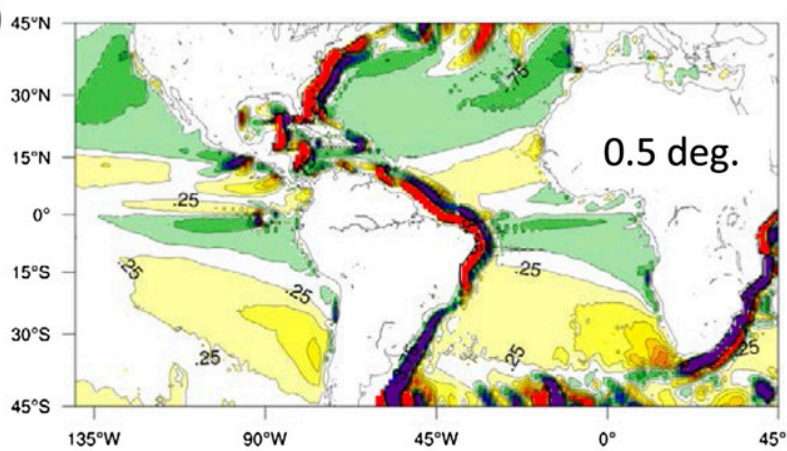

(f)

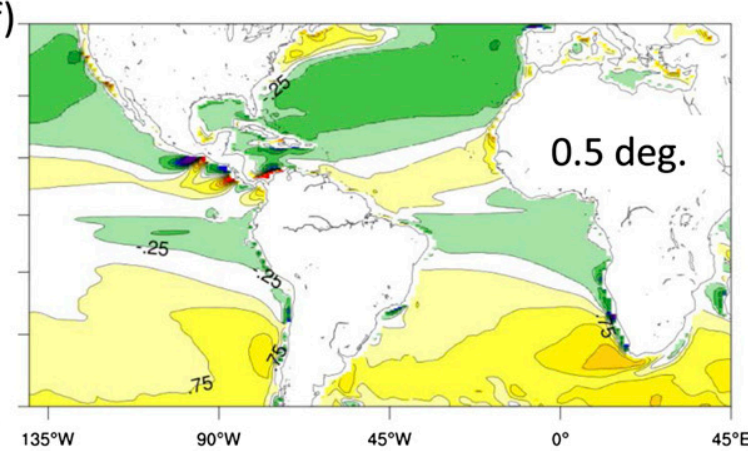

(h)
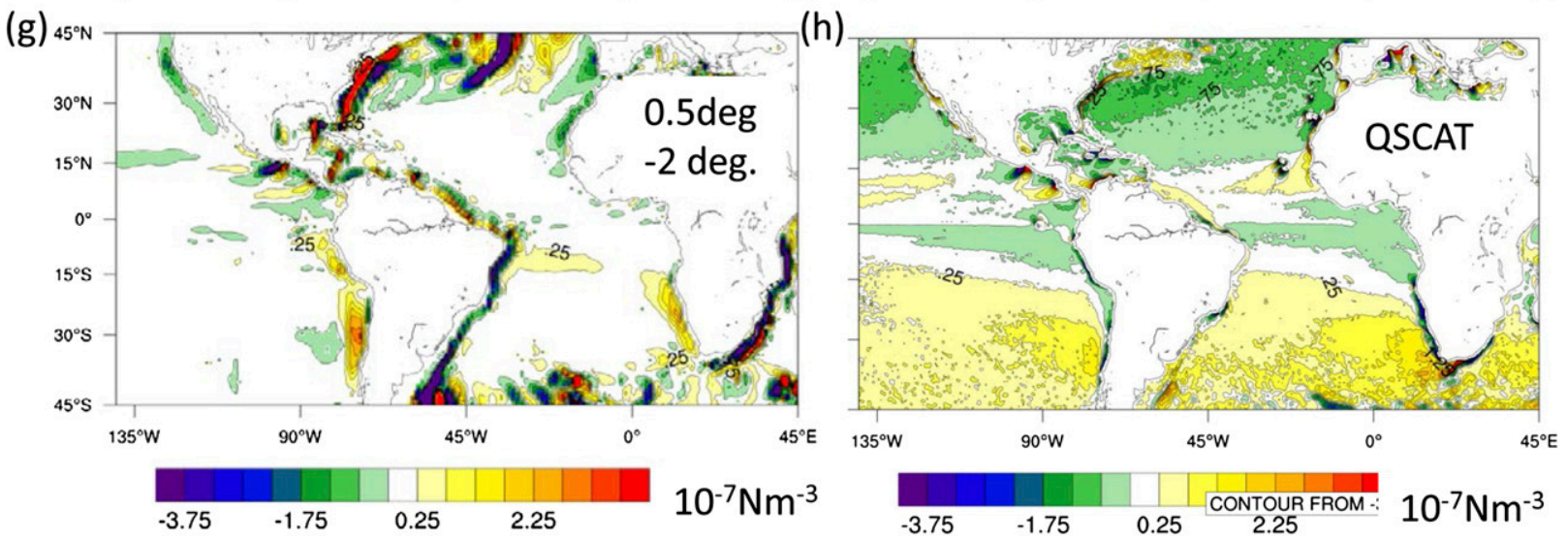

FIG. 3. (a),(c),(e) Term (i) of Eq. (1), which involves the depth-integrated meridional current to 500 m; under Sverdrup balance this term should equal (b),(d),(f) the curl of the wind stress shown, for (top) CCSM $4^{\circ}-2^{\circ}$, (c),(d) CCSM $4^{\circ}-1^{\circ}$, and (e), (f) CCSM4-0.5 . All results are multidecadal annual means. (g) Result of (e) minus (a). (h) Wind stress curl climatology from QuikSCAT (Risien and Chelton (2008). Color bars apply to all panels in that column. The four major upwelling systems are outlined in (a) and (b), where a red outline denotes the Benguela. 
TABLE 2. The distance $L$, in degrees of longitude, of the core of the atmospheric jet from the coast, for different model experiments. The core is defined as the maximum meridional wind stress; similar results are obtained using wind stress magnitude. The coast is taken as the westernmost point of the African land mask. The Cape Frio region is given by $15^{\circ}-20^{\circ} \mathrm{S}$ and the Lüderitz region by $25^{\circ}-28^{\circ} \mathrm{S}$, and $L$ is defined as the minimum offshore jet distance for all latitudes in that range. CCSM4 and nRCM experiments are labeled by the atmosphere resolution or "MOD" for the wind-shifting experiments. The QuikSCAT data are from Risien and Chelton (2008), on a $0.25^{\circ}$ grid, and hence the values of $L$ for QuikSCAT show that the largest wind stress is located at the data point closest to the land mask.

\begin{tabular}{|c|c|c|c|c|c|c|c|}
\hline \multirow[b]{2}{*}{ Region } & \multicolumn{4}{|c|}{ CCSM4 } & \multicolumn{2}{|c|}{$\mathrm{nRCM}$} & \multirow[b]{2}{*}{ QuikSCAT } \\
\hline & $2^{\circ} \mathrm{CAM}$ & $1^{\circ} \mathrm{CAM}$ & $0.5^{\circ} \mathrm{CAM}$ & MOD & $0.5^{\circ} \mathrm{CAM}$ & MOD & \\
\hline Cape Frio & $8^{\circ}$ & $3.5^{\circ}$ & $2^{\circ}$ & $1^{\circ}$ & $1^{\circ}$ & $0.4^{\circ}$ & $0.25^{\circ}$ \\
\hline Luderitz & $6^{\circ}$ & $3.5^{\circ}$ & $2^{\circ}$ & $1^{\circ}$ & $1^{\circ}$ & $0.8^{\circ}$ & $0.25^{\circ}$ \\
\hline
\end{tabular}

Figs. 4d,e). This is consistent with the fact that Sverdrup balance assumes a large-scale, geostrophic flow with small Rossby number and Ekman number (Wunsch 2011; T. Toniazzo 2014, personal communication).

The theory of Fennel et al. (2012) and Junker (2014) discussed in section $1 \mathrm{~b}$ is qualitatively consistent with the results of Fig. 4, with the narrower WSC of CCSM4-0.5 leading to a less dominant countercurrent. More quantitatively, Junker (2014, his Fig. 5.7) finds that the countercurrents start to dominate in a $\beta$-plane model (applicable to long-term averages) for an offshore jet distance of $L=300 \mathrm{~km}$ or more-again consistent with the switch from downwind flow at CCSM4-0.5 (where $L=2^{\circ}$ longitude, $\sim 200 \mathrm{~km}$; Table 2) to a countercurrent in CCSM4-1 $1^{\circ}$, where $L=3.5^{\circ}$ longitude, $\sim 350 \mathrm{~km}$; Table 2 ).

The Sverdrup balance applies to currents in a depth integrated sense, but also has an influence on surface currents. The southward eastern boundary surface currents in CCSM4- $1^{\circ}$ in JJA reaches $0.1 \mathrm{~m} \mathrm{~s}^{-1}$ and extends to $28^{\circ} \mathrm{S}$ (Fig. 4c), as previously shown in Grodsky et al. (2012). In contrast, in CCSM4-0.5 there is a weak northward and westward flow (mostly $<0.05 \mathrm{~m} \mathrm{~s}^{-1}$ ) in most of the Benguela region, with southward currents occurring only off Cape Frio (Angola current) of magnitude $<0.025 \mathrm{~m} \mathrm{~s}^{-1}$ (Fig. 4f).

In addition to the WSC influence on horizontal currents via Sverdrup balance, it also strongly affects the vertical velocity via Ekman pumping dynamics. We use the simplest, linear definition of Ekman pumping velocity $w_{E}$ such that

$$
w_{E}=\frac{\nabla \times \tau}{\rho f} .
$$

Vertical velocity at $45 \mathrm{~m}$ in the CCSM4-1 $1^{\circ}$ case (Fig. 5a) has similar spatial structure to the Ekman pumping field
(Fig. 5b), but slightly weaker magnitude of up to $0.75 \mathrm{~m} \mathrm{day}^{-1}$. In CCSM $4-0.5^{\circ}$ the vertical velocity at $45 \mathrm{~m}$ approaches $0.75-1.0 \mathrm{~m} \mathrm{day}^{-1}$ in small patches (Fig. $5 \mathrm{~d}$ ), and south of $20^{\circ} \mathrm{S}$ it is slightly stronger than the corresponding Ekman pumping field (Fig. 5e). This may be due to the influence of coastal Ekman transport, as the meridional wind stress at the coast is stronger in CCSM $4-0.5^{\circ}$ than in CCSM $4-1^{\circ}$ at many points along the coast (Figs. $5 \mathrm{c}, \mathrm{f}$ ).

The lack of southward boundary currents (to the south of $18^{\circ} \mathrm{S}$ ) and slightly stronger, more localized upwelling velocities in CCSM4- $0.5^{\circ}$ should respectively reduce the warm southward advection and bring cooler water near the surface, relative to $\operatorname{CCSM} 4^{\circ}-1^{\circ}$. This in turn should act to reduce the SST bias, as indicated by Fig. 6, where the SST correction in JJA is nearly $2^{\circ} \mathrm{C}$ along the coast between the Angola/Benguela frontal zone and $30^{\circ} \mathrm{S}$. This compares with maximum reductions in SST of $3^{\circ} \mathrm{C}$ off Peru and Chile, $1.5^{\circ} \mathrm{C}$ off California, and $<1^{\circ} \mathrm{C}$ off northwest Africa: see the supplementary material for brief discussion of the comparison of the different upwelling regions in CCSM4 (available online at http://dx.doi.org/10.1175/JCLI-D-15-0192.s1).

Despite the improvements in the southeast Atlantic, a large bias remains in CCSM4-0.5 $5^{\circ}$, of almost $5^{\circ} \mathrm{C}$ near the Angola/Benguela front (Fig. 1a) and over $3^{\circ} \mathrm{C}$ in much of the Benguela system, showing that much more improvement is needed either in representation of ocean dynamical processes and/or of the low-level cloud field. In the following sections we address the former processes by including a regional, high-resolution ocean model (ROMS).

\section{c. Inclusion of a high-resolution ocean model}

When ROMS is nested in CCSM4 for the southeast Atlantic domain (shown as dashed line in Fig. 1a), the resulting SST difference relative to the standard CCSM4

TABLE 3. As in Table 2, but for the maximum meridional wind stress $\left(\mathrm{N} \mathrm{m}^{-2}\right)$ at coastal points in the specified regions.

\begin{tabular}{|c|c|c|c|c|c|c|c|}
\hline \multirow[b]{2}{*}{ Region } & \multicolumn{4}{|c|}{ CCSM4 } & \multicolumn{2}{|c|}{$\mathrm{nRCM}$} & \multirow[b]{2}{*}{ QuikSCAT } \\
\hline & $2^{\circ} \mathrm{CAM}$ & $1^{\circ} \mathrm{CAM}$ & $0.5^{\circ} \mathrm{CAM}$ & MOD & $0.5^{\circ} \mathrm{CAM}$ & MOD & \\
\hline Cape Frio & 0.02 & 0.08 & 0.1 & 0.1 & 0.04 & 0.09 & 0.12 \\
\hline Luderitz & 0.03 & 0.07 & 0.09 & 0.09 & 0.03 & 0.07 & 0.1 \\
\hline
\end{tabular}


TABLE 4. As in Table 2, but for the maximum meridional wind stress $\left(\mathrm{N} \mathrm{m}^{-2}\right)$ in the core of the jet in the specified regions.

\begin{tabular}{|c|c|c|c|c|c|c|c|}
\hline \multirow[b]{2}{*}{ Region } & \multicolumn{4}{|c|}{ CCSM4 } & \multicolumn{2}{|c|}{$\mathrm{nRCM}$} & \multirow[b]{2}{*}{ QuikSCAT } \\
\hline & $2^{\circ} \mathrm{CAM}$ & $1^{\circ} \mathrm{CAM}$ & $0.5^{\circ} \mathrm{CAM}$ & MOD & $0.5^{\circ} \mathrm{CAM}$ & $\overline{\mathrm{MOD}}$ & \\
\hline Cape Frio & 0.08 & 0.1 & 0.11 & 0.105 & 0.12 & 0.12 & 0.12 \\
\hline Luderitz & 0.07 & 0.105 & 0.095 & 0.09 & 0.11 & 0.09 & 0.1 \\
\hline
\end{tabular}

is similar when CAM is at $1^{\circ}$ (Fig. 7a) or at $0.5^{\circ}$ (Fig. 7b). There is a reduction of SST over some of the domain, of typical magnitude $0.2^{\circ}-0.6^{\circ} \mathrm{C}$, but it is notable that along most of the African coast south of $18^{\circ} \mathrm{S}$ there is not a large change to the SST when ROMS is included, and indeed a weak warming, notably in nRCM- $1^{\circ}$ (Fig. 7a). Although SST is reduced by over $1^{\circ} \mathrm{C}$ west of Cape Frio in nRCM- $1^{\circ}$, this effect is reduced in $\mathrm{nRCM}-0.5^{\circ}$. The reason for the lack of coastal improvement in the control $\mathrm{nRCM}$ experiments, relative to CCSM4, is addressed in the remainder of this subsection.

A notable feature of these control $\mathrm{nRCM}$ experiments is a clear overreduction of wind stress adjacent to the coast (Fig. 8a; compare with QuikSCAT observations in Fig. 2b). Two possible reasons for this are 1) the atmospheric models are the source of the error (Capet et al. 2004) and 2) the default method in CCSM of remapping winds to the ocean grid, which equally weights winds in atmosphere cells over land and winds in cells (a)

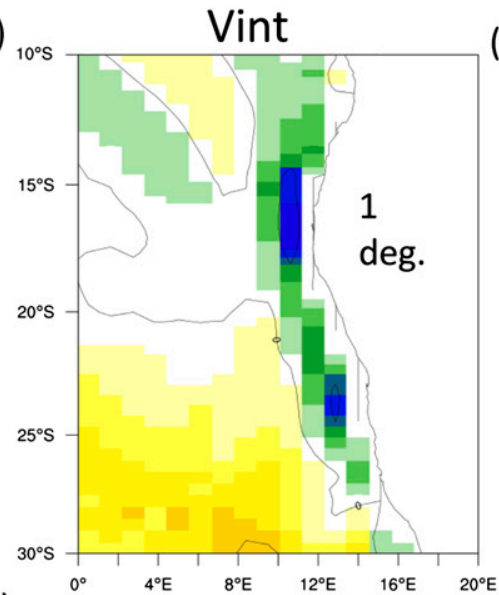

(d)

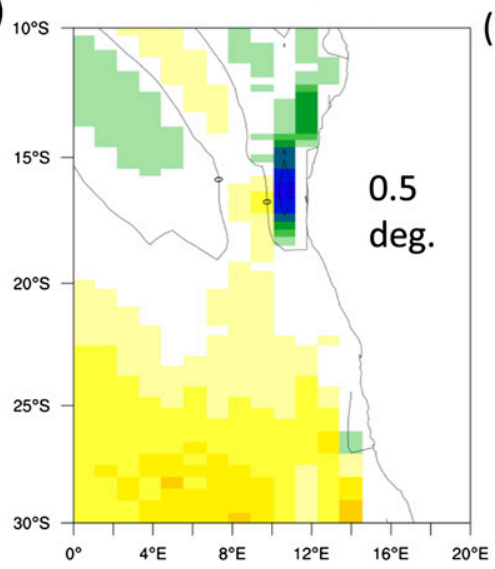

(b),

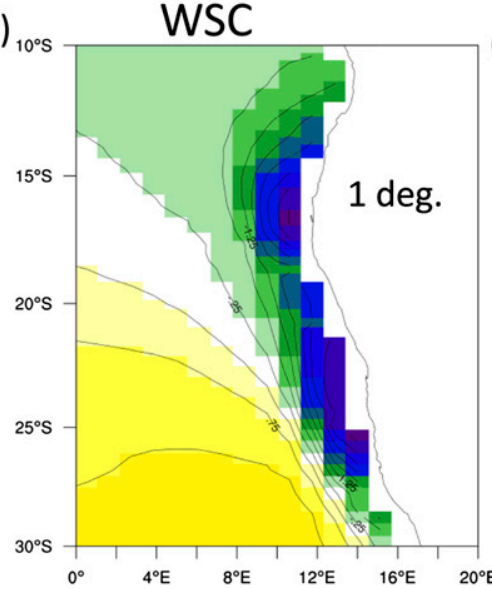

(e) 10

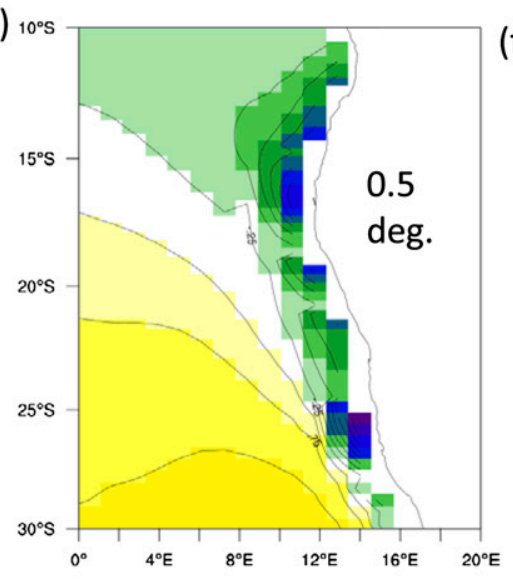

(c)

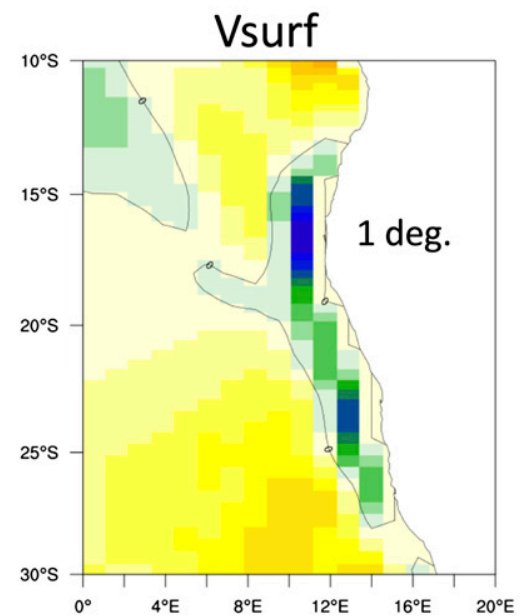

(f)

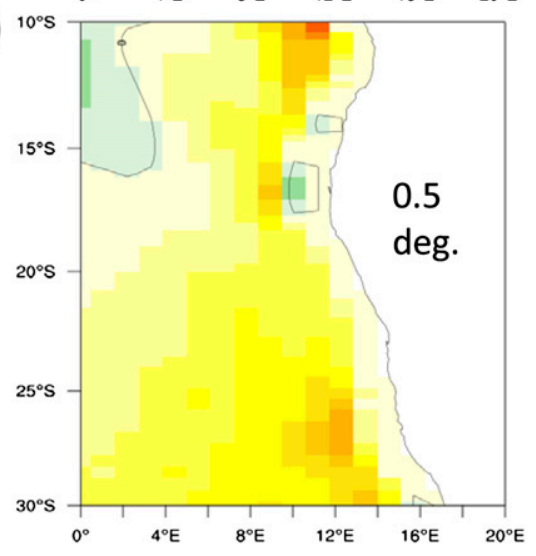

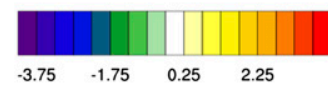

$10^{-7} \mathrm{Nm}^{-3}$

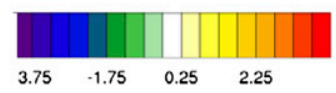

$10^{-7} \mathrm{Nm}^{-3}$

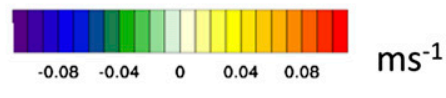

FIG. 4. Sverdrup balance and surface current in JJA. (a),(d) Term (i) of Eq. (1), which involves the depth-integrated meridional current to $500 \mathrm{~m}$. (b),(e) The corresponding curl of the wind stress. (c),(f) The corresponding surface ocean meridional velocity. Results are for (top) CCSM4-1 ${ }^{\circ}$ and (bottom) CCSM4-0.5 . Color bars apply to all panels in that column. 

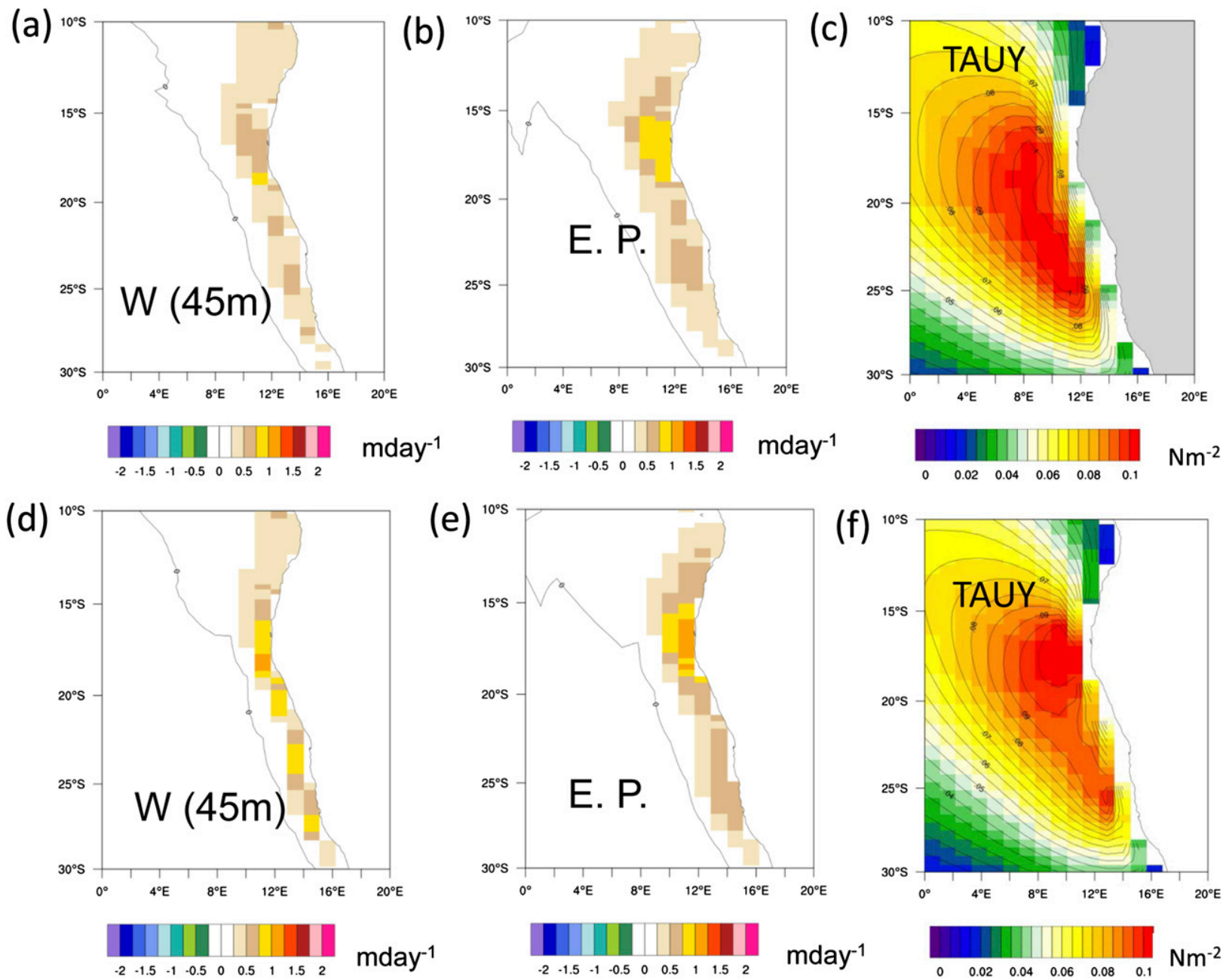

FIG. 5. (a),(d) Vertical velocity at $45 \mathrm{~m}$ in JJA (positive values indicate upwelling), (b),(e) the corresponding Ekman pumping, and (c),(f) the meridional component of surface stress in JJA, in (top) CCSM4-1 ${ }^{\circ}$ and (bottom) CCSM4-0.5 .

over the ocean. The first option may be due to inadequate representation of topography and/or of the boundary layer flow close to coasts, and it typically acts over the 2-4 closest atmosphere grid cells to the coast (i.e., the jet is located $2-4$ grid cells offshore, and the wind rapidly reduces toward shore; Table 2 ). The second option often leads to overly weak wind stress at the coast due to the influence of land drag [see Kara et al. (2007) for a discussion of this issue], and it typically acts on the scale of the nearest atmosphere grid cell to the coast.

Further experiments with nRCM (not shown) revealed that improving the atmosphere-to-ocean remapping method (by neglecting atmosphere data occurring over land cells during the interpolation to ocean model cells) only made a modest improvement to the upwelling system, much less than in the sensitivity experiment of section 4 .
The wind stress magnitude in the closest cells to the coast are mostly $<0.05 \mathrm{~N} \mathrm{~m}^{-2}$ between $28^{\circ}$ and $15^{\circ} \mathrm{S}$ in nRCM $-0.5^{\circ}$ compared to $0.05-0.12 \mathrm{~N} \mathrm{~m}^{-2}$ in QuikSCAT (Fig. 9). The consequent WSC in $\mathrm{nRCM}-1^{\circ}$ (Fig. 10b) $)^{1}$ is stronger in magnitude than CCSM $4-1^{\circ}$ (shown in Fig. $4 \mathrm{~b}$ ) and observations (Fig. 2c), (note different color bars between Fig. 4 and Figs. 2 and 10) and more uniform along the coast, for the reasons outlined in the previous paragraph. As in CCSM4 $-1^{\circ}$, there is a Sverdrup-type response, with southward flow along most of the Benguela coast (Fig. 10a). In nRCM-0.5 the WSC structure

\footnotetext{
${ }^{1}$ The imprint of the atmosphere grid lines on Fig. 10b is due to the use of a bilinear interpolation method from atmosphere to ocean cells: experiments with smoother (higher order) interpolation methods removed this effect but made no change to the results of this paper.
} 


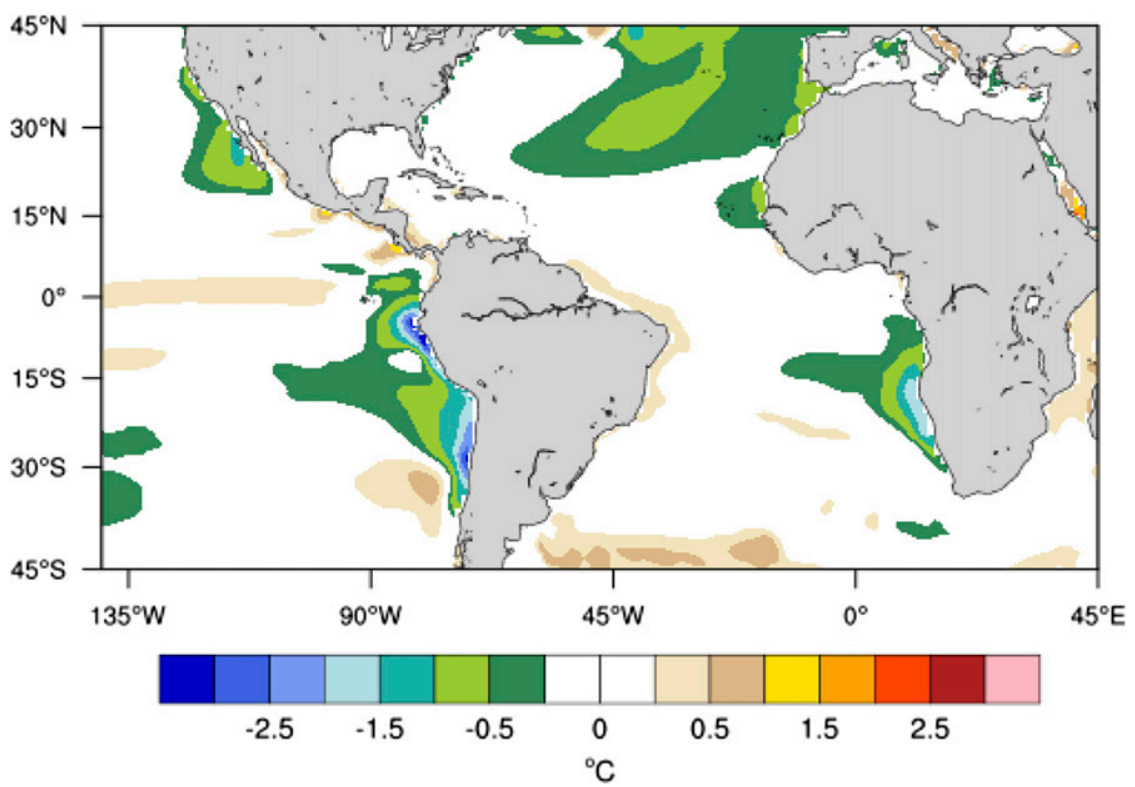

FIG. 6. Difference of SST due to changing the atmospheric resolution in CCSM4. Results shown for CCSM $4-0.5^{\circ}$ minus CCSM $4^{\circ}-1^{\circ}$, in JJA.

(Fig. 10d) is narrower and much stronger than in nRCM- $1^{\circ}$ (Fig. 10b), but despite this the southward flow along the coast in $\mathrm{nRCM}-0.5^{\circ}$ (Fig. 10c) is weaker than in $\mathrm{nRCM}-1^{\circ}$ (Fig. 10a). Hence, as in the corresponding CCSM4 experiments, the Sverdrup balance is less applicable to the case with a higher-resolution atmosphere. However, the stronger curl on the ROMS grid (Fig. 10d) compared to that on the corresponding POP grid (Fig. 4e) may be a reason for a more southward extent of southward currents in $\mathrm{nRCM}-0.5^{\circ}$ compared to CCSM $4-0.5^{\circ}$ (cf. Figs. $4 d$ and $11 \mathrm{c}$ ).

The strong WSC in nRCM- $0.5^{\circ}$ also explains stronger vertical velocities than in CCSM4-0.5 via Ekman pumping, as seen by comparing Figs. 11a,b with Figs. 5d,e. However, the vertical velocities of up to $2 \mathrm{mday}^{-1}$ (Fig. 11a) are still weak compared to forced ocean model simulations (e.g., localized values up to $7 \mathrm{~m} \mathrm{day}^{-1}$; Veitch et al. 2009) and to estimates based on upwelling indices ( $\sim 20 \mathrm{~m} \mathrm{day}^{-1}$; Marchesiello and Estrade 2010), but to our knowledge observations of this quantity are not available (especially for the longer time scales of interest here).

In summary, for the nRCM experiments with the atmosphere grid either at $1^{\circ}$ or $0.5^{\circ}$, the coastal currents are southward, just as in CCSM4-1 $1^{\circ}$, and the vertical upwelling velocity is not much greater than CCSM4 and still too broad in the zonal direction. These are the reasons for the lack of improvement in coastal SST in nRCM compared to CCSM4. The following section discusses whether this result is due to poor coastal wind profiles, by investigating a sensitivity experiment with more realistic coastal winds.

\section{Sensitivity to wind stress in the Benguela upwelling zone}

In this section the response of the ocean to a modified (and improved) coastal wind stress is investigated within the nRCM framework, with an emphasis on how changes to the strength and width of the WSC band affect the ocean currents and temperature structure.

\section{a. Adjusting the coastal wind stress profile in $n R C M$}

Following Capet et al. (2004), who perform sensitivity studies in a stand-alone ROMS simulation of the California Current system, we strengthen the winds near the coast in ROMS but now allow the results to affect the global climate system by using the nRCM. The modification is done by adding $1^{\circ}$ to the longitude value associated with CAM cells in the original longitude range $10^{\circ}-16^{\circ} \mathrm{E}$, before the data are passed to ROMS to compute air-sea fluxes. (Some merging is done at the edges of that range to smooth the transition.) This method, which is purely ad hoc but designed to make the model coastal winds better mimic observed values, allows the atmospheric jet to shift closer to the coast and with less wind drop-off near the coast (see Fig. 8b and compare with Figs. $8 \mathrm{a}$ and $2 \mathrm{~b}$ ). Note that a related experiment was performed by Toniazzo (2010), who shifted the orography of South America by one model grid 
(a)

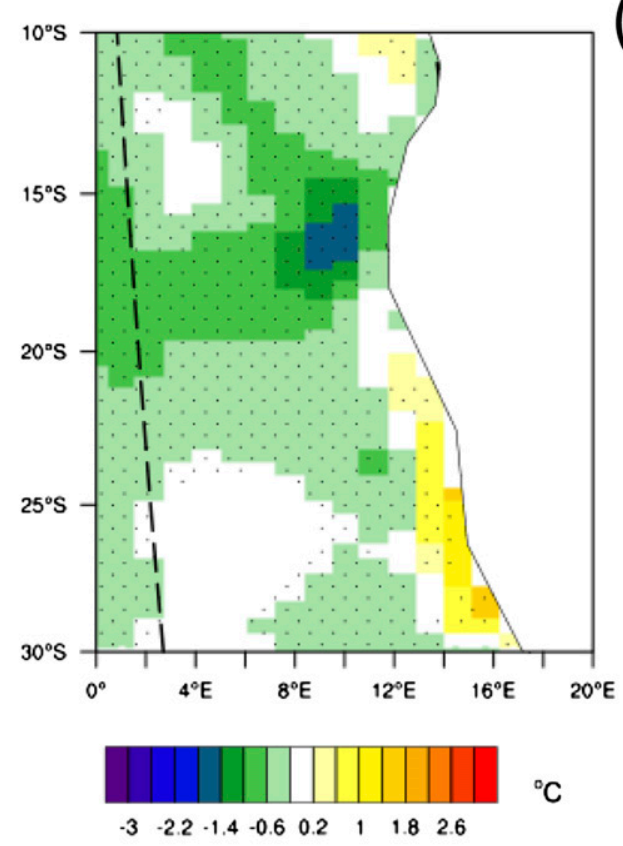

(b)

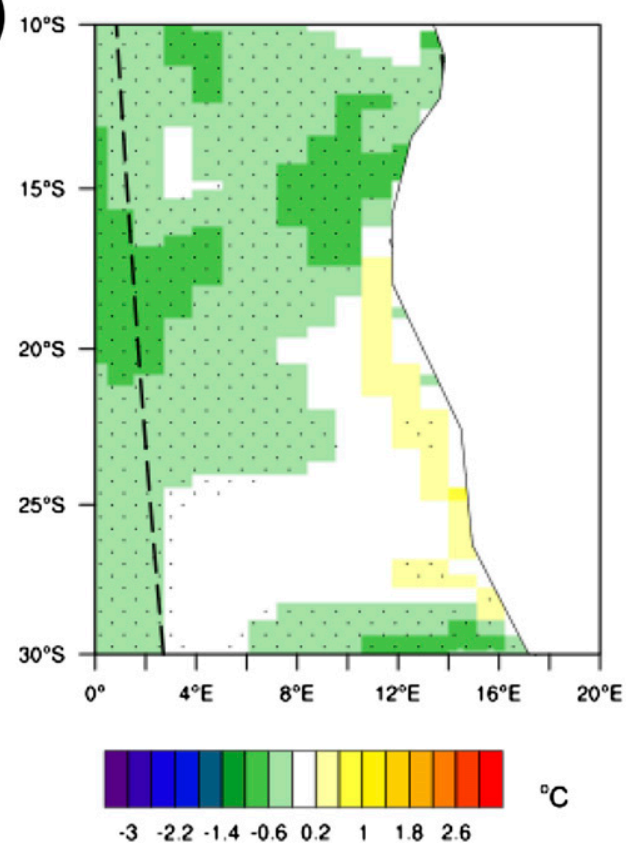

FIG. 7. SST differences of nRCM from equivalent CCSM4 run, for JJA: (a) nRCM- $1^{\circ}$ minus CCSM4- $1^{\circ}$ and (b) nRCM- $0.5^{\circ}$ minus CCSM4-0.5 .

point to the east (on a coarse $3.75^{\circ}$ grid) in a GCM, and found improvements to winds and SST off the coast of South America.

The new simulation is referred to as nRCM-MOD, and in this case the coastal wind stress magnitude varies from 0.05 to $0.1 \mathrm{~N} \mathrm{~m}^{-2}$ (Fig. 9), closer to QuikSCAT values with local maxima offshore of Cape Frio and around $26^{\circ}-27^{\circ} \mathrm{S}$ (Lüderitz upwelling), as observed. The resulting WSC in nRCM-MOD is strong only in a very narrow band close to the coast (Fig. 10f), mostly within the QuikSCAT "blind zone" (white masked coastal region in Fig. 2c).

\section{b. Ocean velocity response to adjusted winds}

The nRCM-MOD results are more consistent with coastal offshore Ekman transport than the broader Ekman pumping- and Sverdrup balance-driven dynamics of $n R C M-0.5^{\circ}$. In nRCM-MOD an equatorward coastal jet is formed along the Benguela coastline as far north as $18^{\circ} \mathrm{S}$, of strength $0.1-0.2 \mathrm{~m} \mathrm{~s}^{-1}$ (Figs. 12b,d), contrasting with the poleward flow in nRCM-0.5 (Figs. 12a,c). The reason for the dramatic change is as follows. The theory of Fennel et al. (2012) and Junker (2014) shows that the coastal Ekman transport part of the ocean response exhibits downwind currents trapped within a Rossby radius of the coast. Having the atmosphere jet core located close to the coast $\left(<1^{\circ}\right)$ in nRCM-MOD (Table 2), without exhibiting excessive dropping off toward the coast, allows for strong winds within the Rossby radius of the coast $(\sim 50 \mathrm{~km})$ to force the downwind current jet. In contrast, the winds are too weak in this zone in $\mathrm{nRCM}-0.5^{\circ}$, and the currents are WSC-driven and thus flow upwind.

There is also more of an offshore component to the near-coastal surface current in nRCM-MOD, consistent with offshore Ekman transport. Close to the coast the offshore component ${ }^{2}$ is typically between 0.05 and $0.1 \mathrm{~m} \mathrm{~s}^{-1}$, whereas in $\mathrm{nRCM}-0.5^{\circ}$ it has a magnitude of $<0.025 \mathrm{~m} \mathrm{~s}^{-1}$ (not shown). Meanwhile the southward Angola Current, the meridional component of which reaches $0.4 \mathrm{~m} \mathrm{~s}^{-1}$ in nRCM-0.5 (Fig. 12a), is mostly removed at the surface in nRCM-MOD (Fig. 12b). The observed Angola Current is believed to be partly WSC driven (Colberg and Reason 2006), and the setup of the nRCM-MOD experiment may have removed too much of the WSC at these latitudes. However, vertical sections of the current (Fig. 13b) show that there is a strong southward flow just below the surface.

In addition to changes in the horizontal flow, the vertical velocity field shows localized, strong coastal upwelling in the nRCM-MOD experiment (Figs. 11d,f), contrasting with broader, weaker upward velocities in nRCM- $0.5^{\circ}$ (Figs. 11a,c). For nRCM-MOD, the vertical

\footnotetext{
${ }^{2}$ The coastline is typically rotated less than $20^{\circ}$ from north/south, and the offshore component was computed taking this into account.
} 

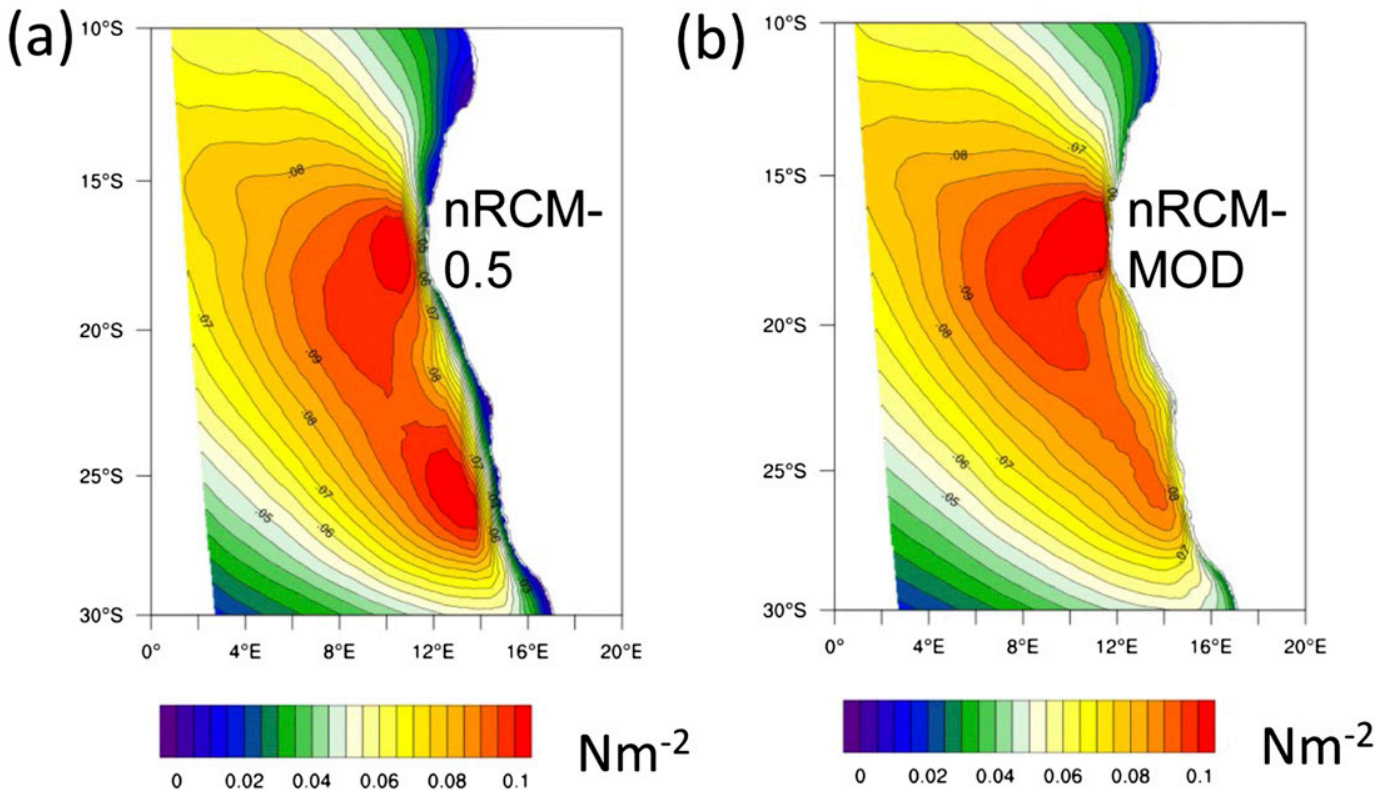

FIG. 8. Meridional component of wind stress in JJA, in the ROMS part of (a) nRCM-0.5 and (b) nRCM-MOD.

velocity field immediately adjacent to the coast is much stronger than the Ekman pumping (cf. Figs. 11d and 11e south of $20^{\circ} \mathrm{S}$ ), unlike the situation with nRCM-0.5 (Figs. 11a,b). Close inspection reveals coastal maxima in vertical velocity south of $20^{\circ} \mathrm{S}$ of $3-4 \mathrm{~m} \mathrm{day}^{-1}$ in nRCM-MOD compared to $<1.5 \mathrm{~m} \mathrm{day}^{-1}$ in nRCM- $-0.5^{\circ}$ (Figs. 11c,f).

Vertical sections in the region of the Angola Current show that $\mathrm{nRCM}-0.5^{\circ}$ has a strong, deep, and wide southward current that intensifies at the surface with a weaker northward flow offshore (Fig. 13a). The corresponding vertical profile from nRCM-MOD (Fig. 13b) shows a narrower and weaker southward current (consistent with the narrower WSC) that weakens toward the surface, (possibly due to the stronger coastal wind stress in $\mathrm{nRCM}-\mathrm{MOD}$ between $15^{\circ}$ and $20^{\circ} \mathrm{S}$ driving a more northward surface flow to counteract the curl-driven southward flow).

Farther south, a section meeting the coast at $25.5^{\circ} \mathrm{S}$ shows very different behavior between the model runs. The model $\mathrm{nRCM}-0.5^{\circ}$ again exhibits inshore southward flow, extending to beyond 300-m depth, and offshore northward flow (Fig. 13c), while nRCM-MOD has equatorward flow everywhere in top $300 \mathrm{~m}$ (Fig. 13d). This implies that Sverdrup balance is not met here, as the WSC is negative (Fig. 10f), and indeed the vertical integral of meridional velocity is positive near the coast at latitudes south of $20^{\circ} \mathrm{S}$ in this run (Fig. 10e). As discussed above this may relate to the narrow scale of the strong WSC in nRCM-MOD invalidating the approximations of Sverdrup balance.

\section{c. Ocean temperature response to adjusted winds}

In the Angola Current the corresponding potential temperature sections reveal an offshore doming of isotherms in $\mathrm{nRCM}-0.5^{\circ}$, between $11^{\circ}$ and $12^{\circ} \mathrm{E}$ due to

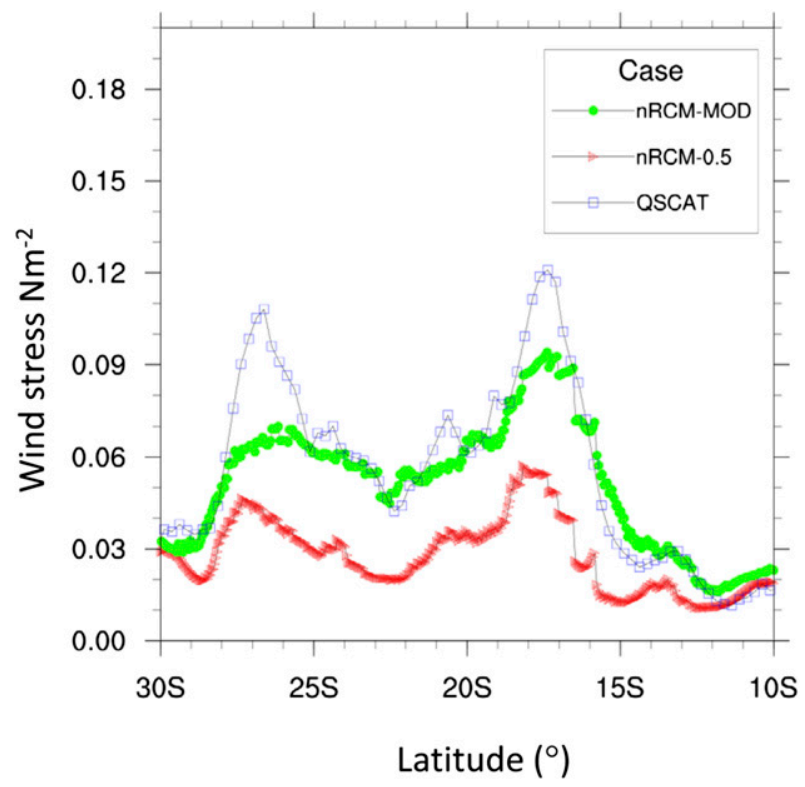

FIG. 9. Wind stress at coastal points as a function of latitude in JJA. The stress is the magnitude of time-averaged vector components, at the closest data point to the West Africa coastline. Data are from the ROMS part of $\mathrm{nRCM}-0.5^{\circ}$ (red), the corresponding field from nRCM-MOD (green), and QuikSCAT (blue) (Risien and Chelton 2008). See legend. 
(a)

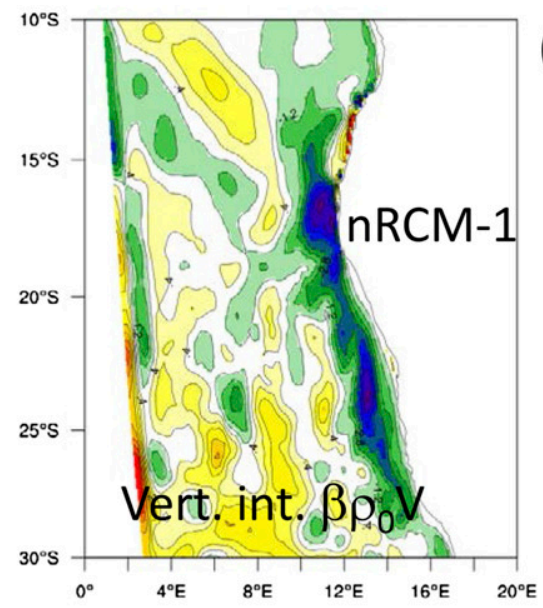

(c)

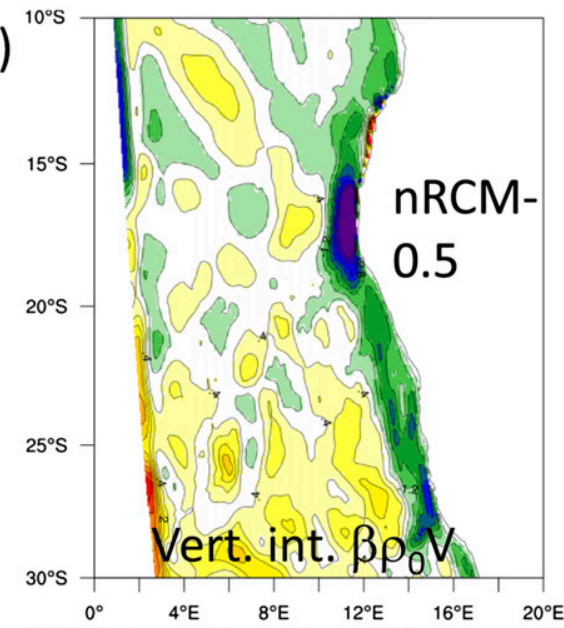

(e)

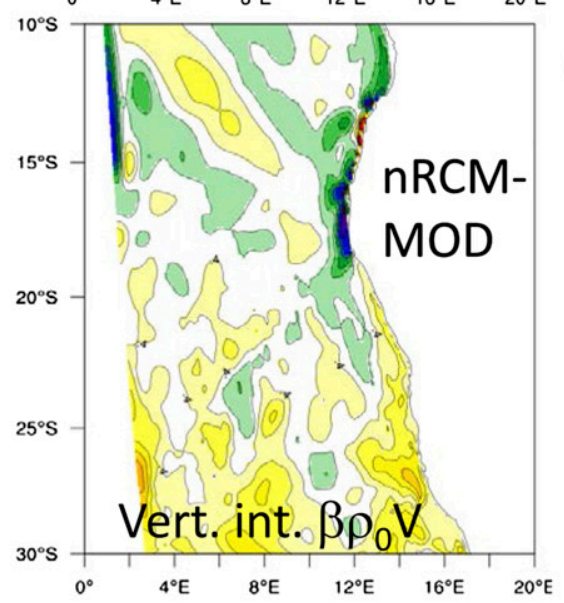

(b)

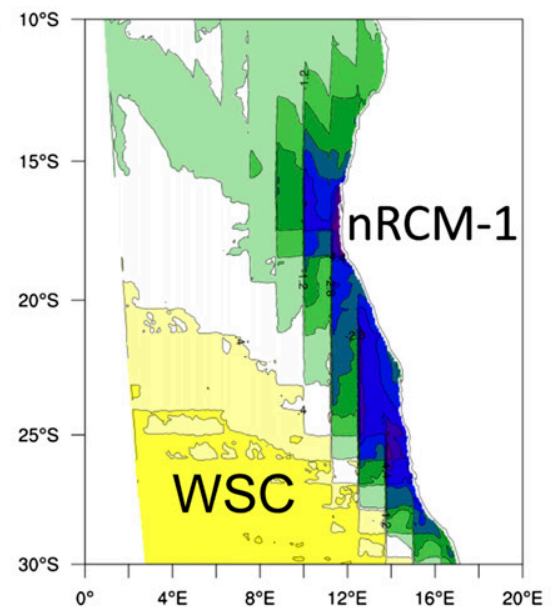

(d)

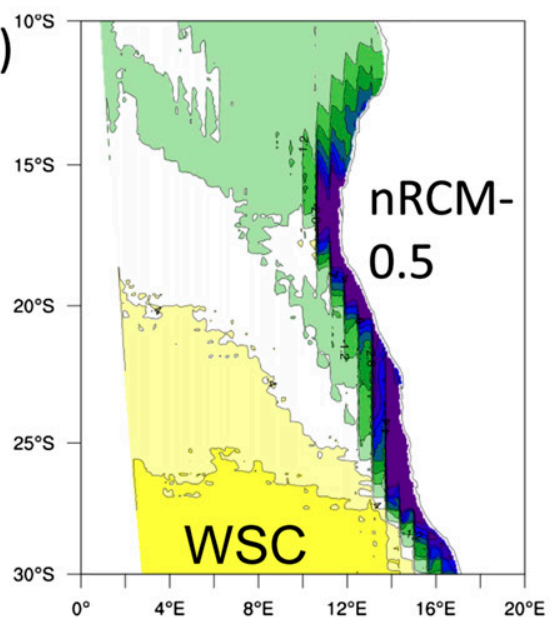

(f)

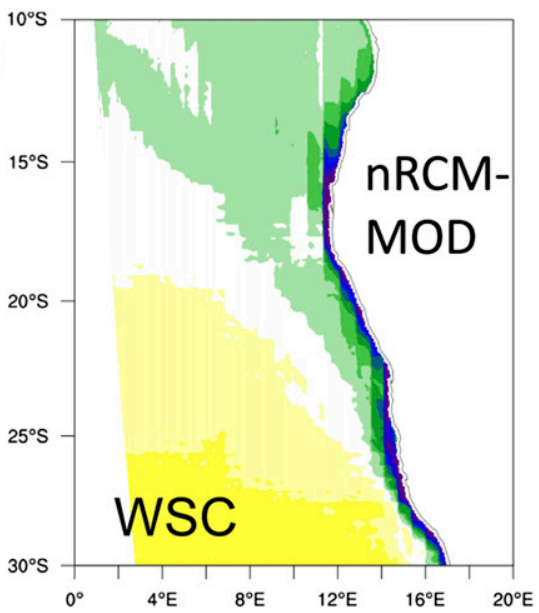

$10^{-7} \mathrm{Nm}^{-3}$

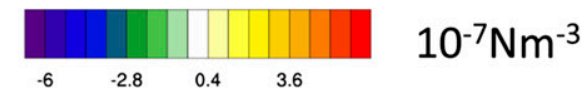

FIG. 10. Sverdrup balance in ROMS in JJA. (a),(c),(e) Term (i) of Eq. (1), which involves the depthintegrated meridional current to $500 \mathrm{~m}$, and (b),(d),(f) the corresponding curl of the wind stress, for (top) $\mathrm{nRCM}-1^{\circ}$, (middle) $\mathrm{nRCM}-0.5^{\circ}$, and (bottom) nRCM-MOD. Color bars apply to all panels in that column. 
(a)

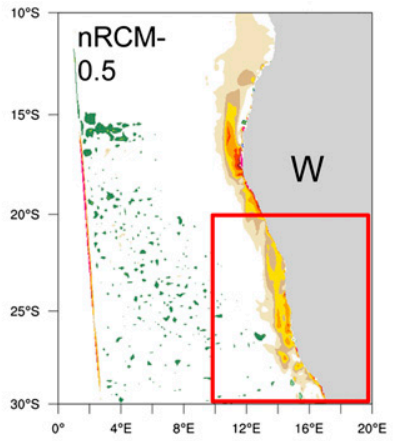

(d)

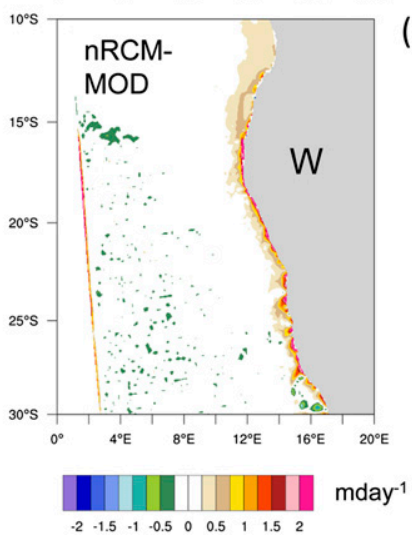

(b)

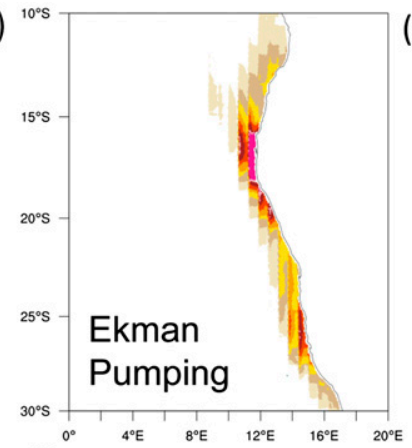

(e)

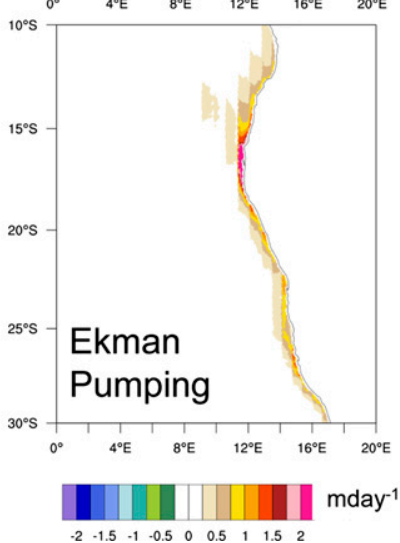

(c)

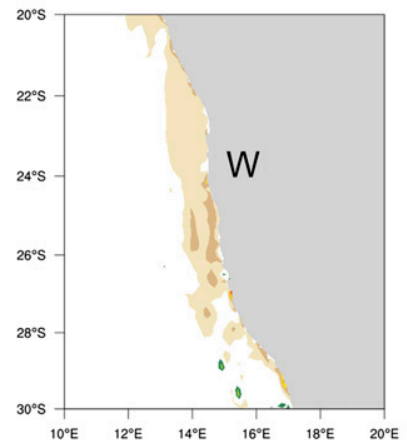

(f)

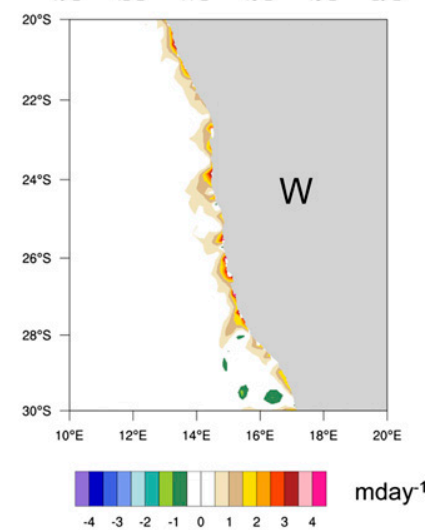

FIG. 11. (a),(d) Vertical velocity at $45 \mathrm{~m}$ in ROMS part of nRCM in JJA. (b),(e) Corresponding Ekman pumping. (c),(f) Close ups of vertical velocity for box shown in (a). Data are for (top) $\mathrm{nRCM}-0.5^{\circ}$ and (bottom) nRCM-MOD. Color bars at bottom apply to the column above; (c) and (f) use a different color range from the other panels.

Ekman pumping, with downward sloping isotherms at the coast (Fig. 14a), while nRCM-MOD has less doming and upward sloping isotherms near the coast in the upper $50 \mathrm{~m}$ (Fig. 14b). From Figs. 13a and 13b it can be seen that the core of the undercurrent is at the surface in $\mathrm{nRCM}-0.5^{\circ}$ and at 50-m depth in nRCM-MOD: thermal wind ${ }^{3}$ then implies that temperature should increase toward the coast in $\mathrm{nRCM}-0.5^{\circ}$, while in nRCM-MOD it should decrease toward the coast in the upper $50 \mathrm{~m}$ and increase coastward below $50-\mathrm{m}$ depth, as indeed seen in Figs. 14a and 14b. The temperature sections for the southern section (Figs. 14c,d) show similar results to that seen farther north and are again consistent with thermal wind.

As a consequence of the equatorward boundary currents and more intense upwelling in the nRCMMOD experiment, the SST cools significantly compared to the $\mathrm{nRCM}-0.5^{\circ}$ experiment, as evidenced in

\footnotetext{
${ }^{3}$ Geostrophy is expected to approximately hold in the alongshore direction but not across-shore (McCreary et al. 1987; T. Toniazzo 2015, personal communication), implying that thermal wind balance can be used here.
}

comparing Figs. 15a and 15b. The nRCM-MOD experiment has a much more realistic SST upwelling and frontal structure when compared against observations (e.g., Reynolds et al. 2007; $0.25^{\circ} \mathrm{SST}$, referred to here as OISST, and HadISST, shown in Figs. 15c and 15d, respectively) and is more consistent with ROMS simulations forced with QuikSCAT winds (Veitch et al. 2010; Fennel et al. 2012). In particular the alongshore profile of SST is improved in $\mathrm{RCM}-\mathrm{MOD}$ (Fig. 15e), as well as the zonal SST gradient near the coast (Fig. 15f), when comparing model against OISST, which resolves ocean fronts better than HadISST. At the latitude of Luderitz $\left(26^{\circ}-27^{\circ} \mathrm{S}\right)$ the SST in the cell adjacent to land is $13^{\circ} \mathrm{C}$ in both nRCM-MOD and OISST (Figs. 15e,f) compared to $17^{\circ} \mathrm{C}$ in nRCM$0.5^{\circ}$. However, farther north along the coast, and away from $50-100 \mathrm{~km}$ of the shore, the SST is still too warm in the nRCM-MOD experiment compared to observations.

The overall effect of changing the structure of the coastal winds is summarized in Figs. 16a and 16b. The difference in SST between nRCM-MOD and nRCM$0.5^{\circ}$ on the ROMS grid reveals $3^{\circ}-4^{\circ} \mathrm{C}$ differences at the coast (Fig. 16a). When remapped onto the POP 
(a)

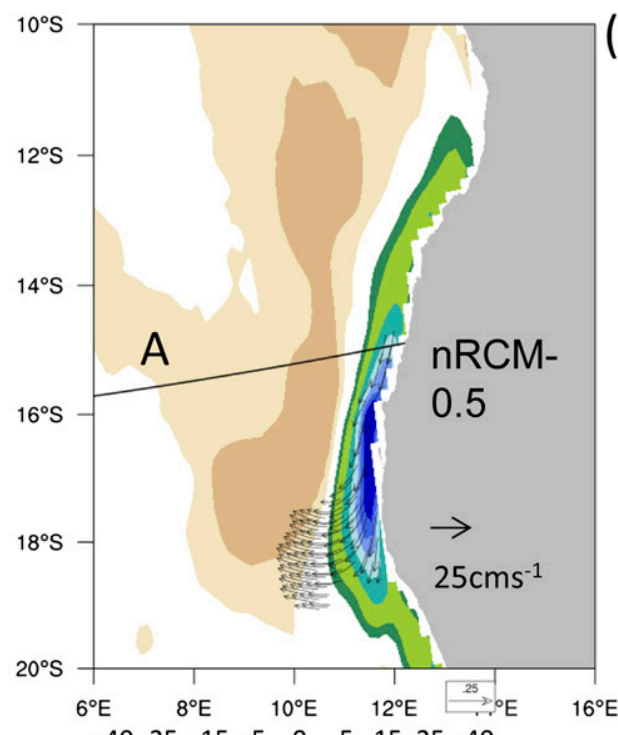

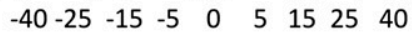

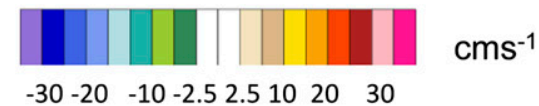

(c)

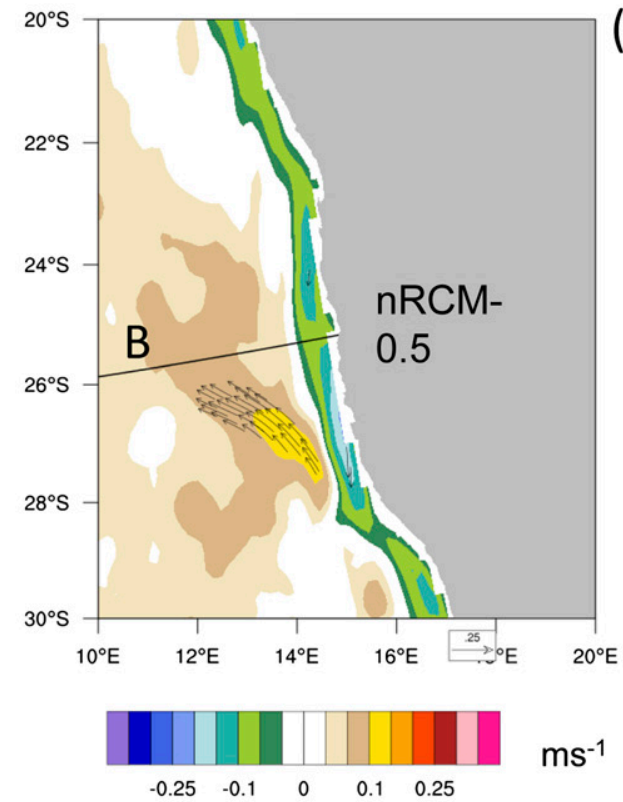

(b)
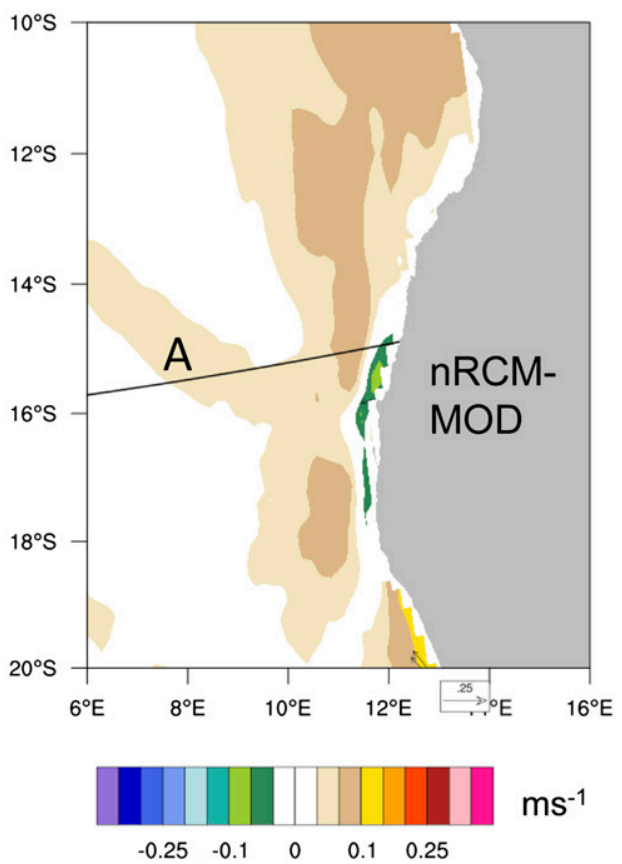

(d)

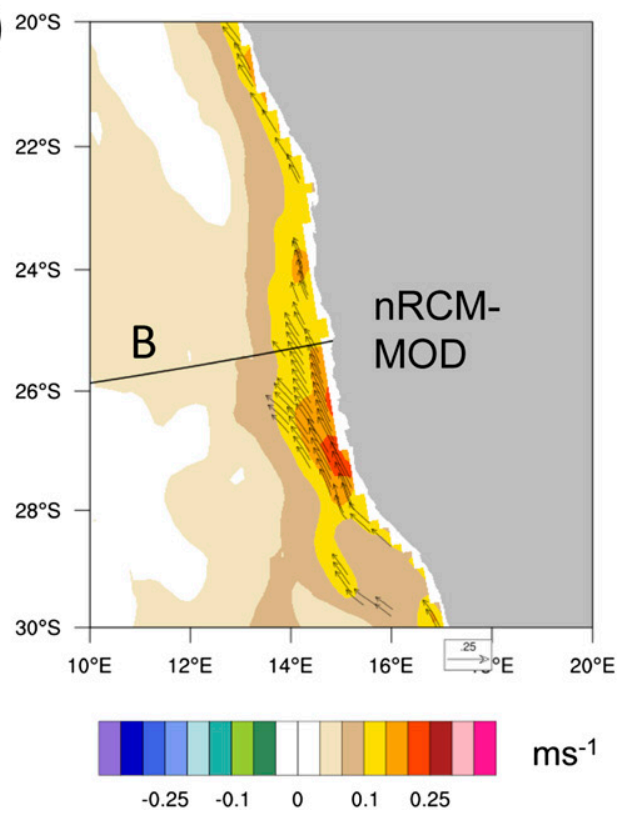

FIG. 12. Time-mean surface current (arrows) and meridional velocity (color) in JJA. Only vectors with magnitude $>0.15 \mathrm{~m} \mathrm{~s}^{-1}$ are shown, and data are subsampled every 3 points in the ROMS coordinate directions. Shown are the (a),(b) Angola current/northern Benguela system, from $10^{\circ}$ to $20^{\circ} \mathrm{S}$, and (c),(d) main Benguela system, from $20^{\circ}$ to $30^{\circ} \mathrm{S}$, for the ROMS part of (left) $\mathrm{nRCM}-0.5^{\circ}$ and (right) nRCM-MOD. Lines A and B are referred to in Fig. 13. Color bar is nonlinear and labeled in full in (a) using centimeter per second units. A $25 \mathrm{~cm} \mathrm{~s}^{-1}$ scale arrow is also shown in (a).

grid (via a conservative, area-average technique), the consequent composite SST difference reaches between $2^{\circ}$ and $3^{\circ} \mathrm{C}$ along the Benguela coast (Fig. 16b). The nRCM-MOD experiment clearly has a large impact on SST in the coastal Benguela zone. We may ask to what extent this fixes the CCSM4-0.5 $5^{\circ}$ SST bias (shown in Fig. 1a)? The large maximum of $4^{\circ}-5^{\circ} \mathrm{C} \mathrm{SST}$ error located around Cape Frio $\left(\sim 17^{\circ} \mathrm{S}\right)$ no longer appears in the results from the nRCM-MOD experiment (Fig. 16c). However, a bias of $2^{\circ} \mathrm{C}$ still persists 

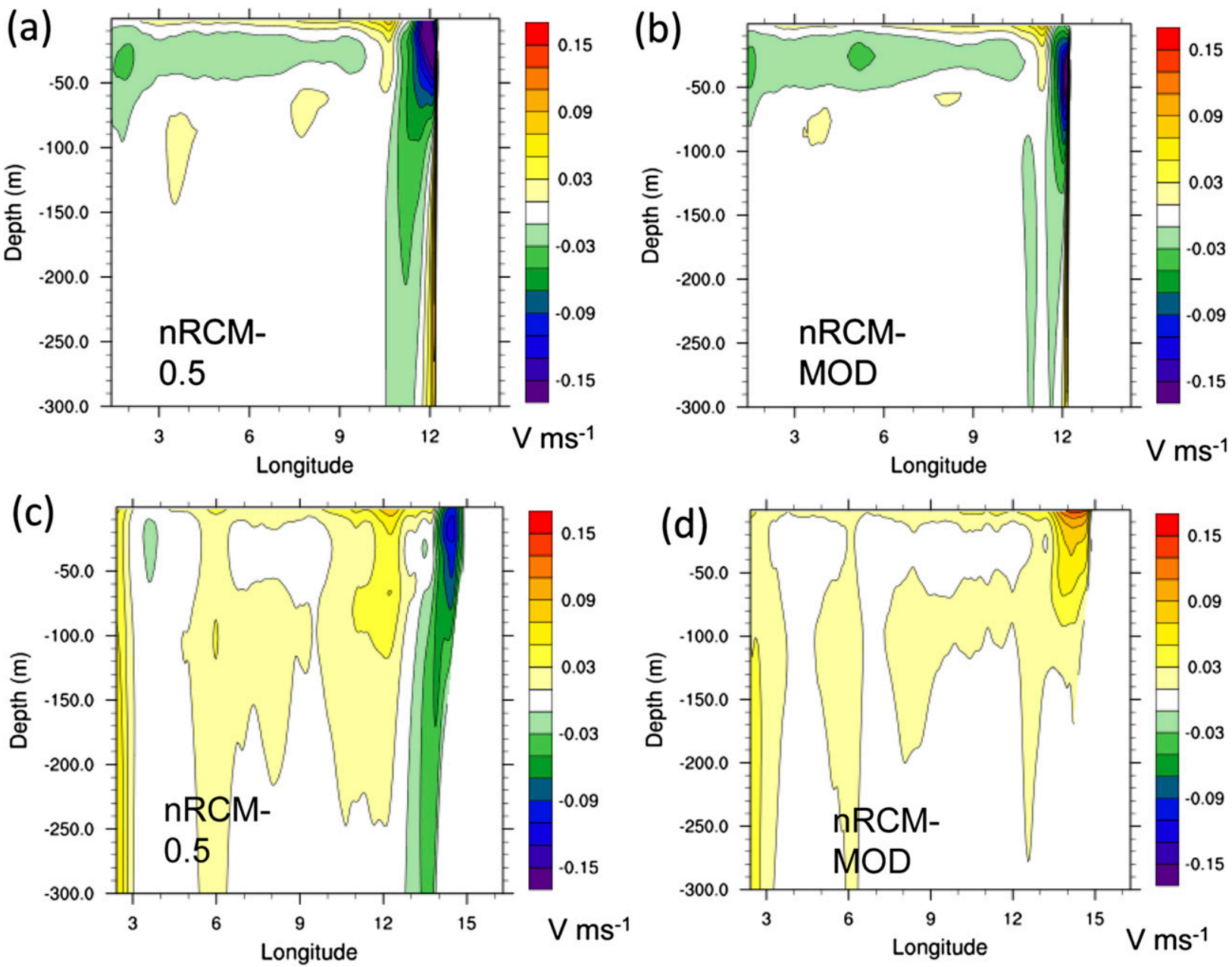

FIG. 13. Meridional velocity sections vs longitude and depth, along (a),(b) line A shown in Figs. 12a,b and (c),(d) line B shown in Fig. $12 \mathrm{c}, \mathrm{d}$, from (left) nRCM- $0.5^{\circ}$ and (right) nRCM-MOD.

throughout the Benguela upwelling zone, which is relatively uniform in the meridional direction for latitudes south of $10^{\circ} \mathrm{S}$, except for a reduction in its zonal extent to the south.

\section{Remote response to correcting Benguela model bias}

The remote response in the equatorial Atlantic to improving the winds off the Benguela coast is small in our experiments (Fig. 16b). This is very different to the large response seen in LD06 to correcting the eastern boundary temperature and salinity bias. To investigate this discrepancy further, we performed similar experiments to LD06, but varying the spatial region where temperature and salinity were restored to observations. First, for verification purposes, the LD06 experiment was repeated but with the newer CCSM4-0.5 ${ }^{\circ}$ system described in section 2a (referred to as the LARGE domain experiment: the restoring region is shown in Fig. 17a). The results were similar to LD06: much of the SST bias of $1^{\circ}-3^{\circ} \mathrm{C}$ in CCSM4-0.5 $5^{\circ}$ in the equatorial region east of $10^{\circ} \mathrm{W}$ was removed (Fig. 17a), and there was a reduction of the southern ITCZ bias by up to $3 \mathrm{~mm} \mathrm{day}^{-1}$, so that much of the positive precipitation bias is also removed (cf. Figs. $1 \mathrm{~b}$ and $17 \mathrm{c}$ ).

Next a more regionally constrained experiment was performed, with the temperature and salinity off western Africa restored only between $12^{\circ}$ and $30^{\circ} \mathrm{S}$, and offshore to $8^{\circ} \mathrm{E}$, thus focusing on the response to restoring outside the equatorial region (SMALL domain experiment). Restoring in this domain (Fig. 17b) leads to nearly $40 \%$ of the equatorial SST correction made by the LARGE domain (up to $1^{\circ} \mathrm{C}$ compared to up to $2.6^{\circ} \mathrm{C}$ ) as well as a reduction of the southern ITCZ bias by around $2 \mathrm{~mm} \mathrm{day}^{-1}$ (Fig. 17d). 

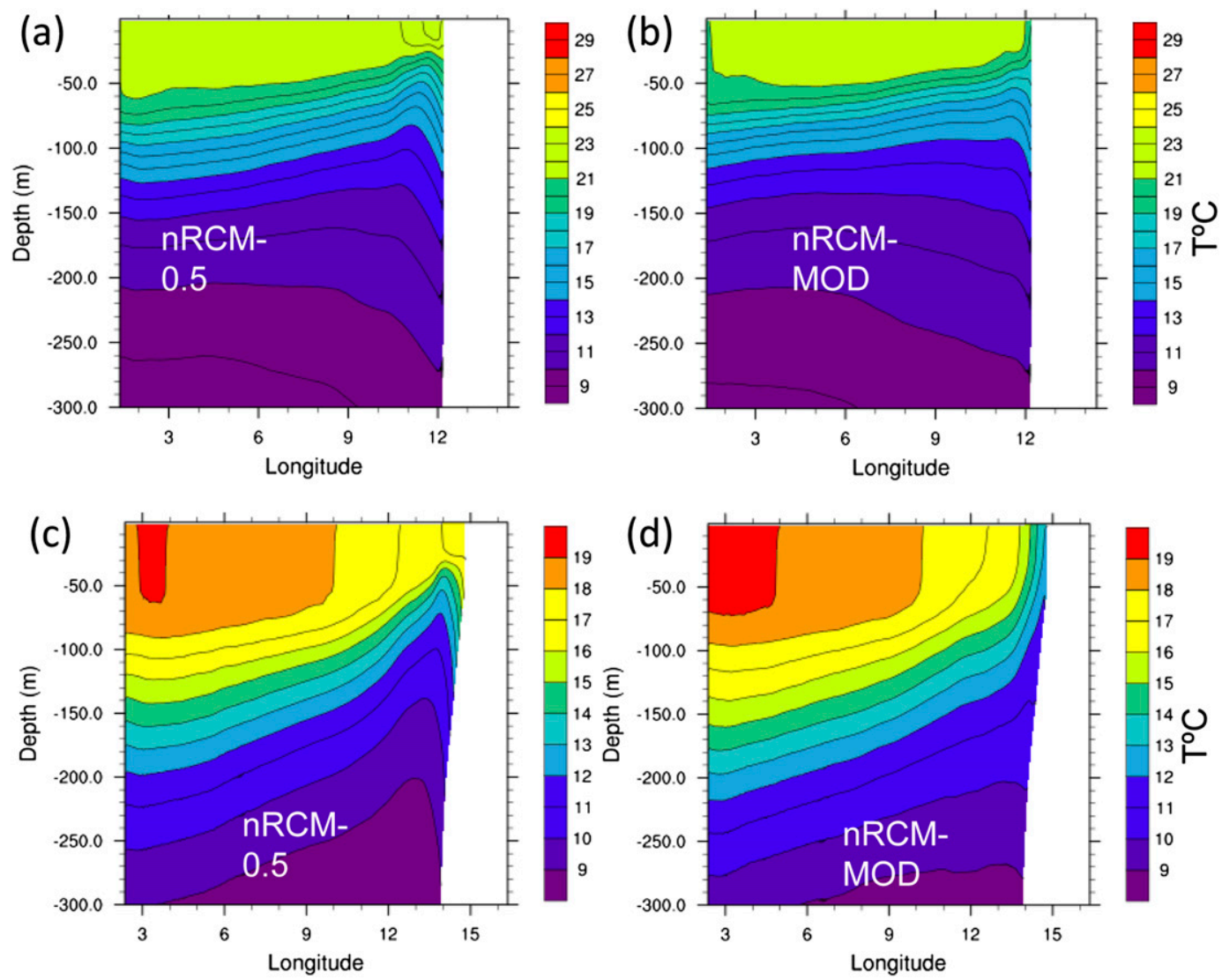

FIG. 14. Potential temperature sections $\left({ }^{\circ} \mathrm{C}\right)$ vs longitude and depth are along (a),(c) line A in Figs. 12a,b and (b),(d) line B shown in Figs. 12c,d, from (left) nRCM- $0.5^{\circ}$ and (right) nRCM-MOD. Note change of temperature color range from upper row to lower row.

In both the SMALL restore case (Fig. 17b) and in nRCM-MOD (Fig. 16b), SST has been corrected mostly in the ABF zone and farther south in the Benguela upwelling, so why is it only the restoring run that has a substantial remote effect? Some possible reasons are as follows. In the SMALL restore case, SST differences from CCSM4- $0.5^{\circ}$ are large at Cape Frio by design $\left(5^{\circ} \mathrm{C}\right.$; the magnitude of the SST bias of CCSM4-0.5 relative to Levitus), and differences up to $3^{\circ} \mathrm{C}$ occur at the western edge of the restoring region $\left(8^{\circ} \mathrm{E}\right)$ off Cape Frio (Fig. 17b). By contrast, differences between RCM-MOD and nRCM $-0.5^{\circ}$ reach only $2^{\circ}-3^{\circ} \mathrm{C}$ at Cape Frio (when remapped onto the POP grid) and rapidly drop away to zero by $8^{\circ} \mathrm{E}$ (Fig. 16b). Therefore both the weaker magnitude and smaller spatial extent of the SST correction on the eastern boundary lead to the smaller remote response in nRCM-MOD compared to the SMALL restore case. The restore experiment not only fixes errors in SST due to inadequate upwelling and coastal currents, but also corrects for shortwave radiation biases and remote ocean temperature biases, which also impact SST in the eastern boundary region. Correction of all these factors, and not just the coastal upwelling and currents, is required to force a large remote response.

\section{Discussion}

\section{a. Does Sverdrup balance hold in the observed Benguela upwelling system?}

In some of the simulations presented in this manuscript, an approximate Sverdrup balance holds in the Benguela coastal region, and we argue that this results in unsuitable transport and velocities because of deficiencies with the WSC. However, it may be asked how appropriate Sverdrup balance is when the WSC is realistic? In the interior subtropical gyres several papers suggest Sverdrup balance is a good approximation for a long time average [e.g., Wunsch (2011) and references therein], but the situation at eastern boundaries is less clear. Whereas in some other global climate models the balance does seem to mostly hold in the Benguela [e.g., the U.K. High-Resolution Global Environment Model (HiGEM); see Figs. 2b,d,f of Thomas et al. (2014), which show southward transport in the model at the coast and 
(a)

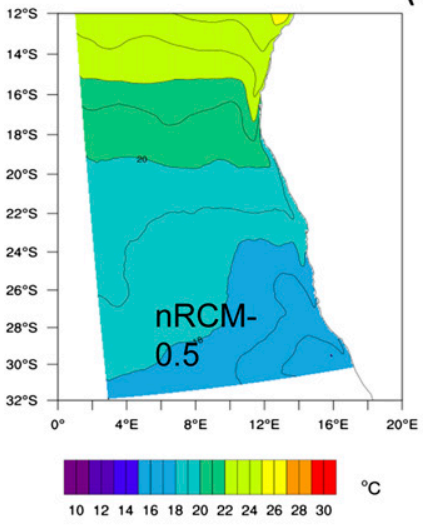

(e)

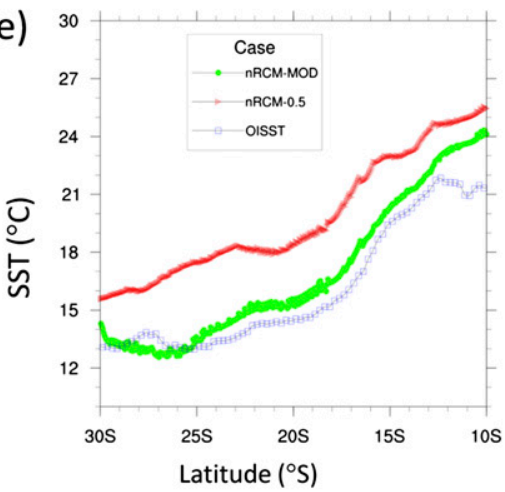

(c)

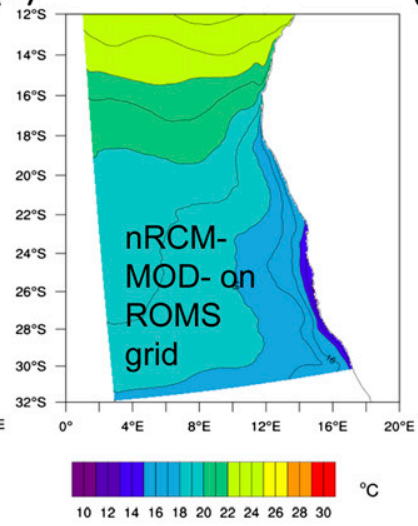

(f)

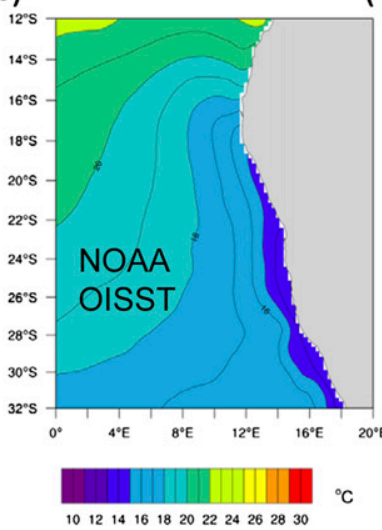

d)

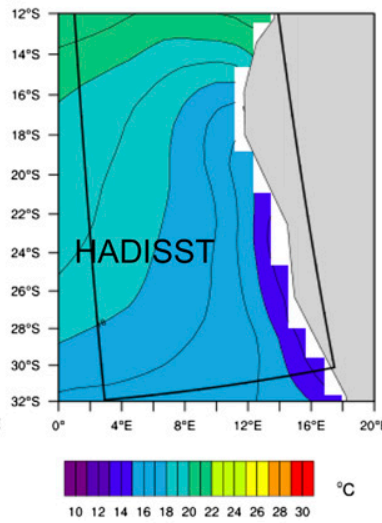

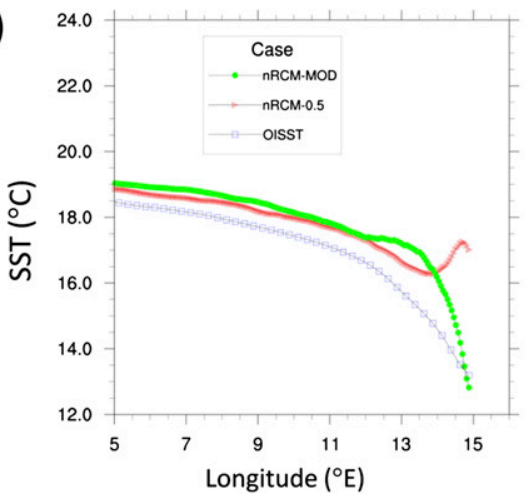

FIG. 15. Top-level temperature (taken as SST), for JJA seasonal mean, from the (a) ROMS part of nRCM-0.5 , (b) ROMS part of nRCM-MOD experiment, (c) NOAA analysis of observed SST (OISST; Banzon et al. 2014), and (d) HadISST (1870-99) gridded onto POP grid. (e) The time-mean SST along the coast, as a function of latitude, using nearest grid cells to coast, for (see legend) nRCM- $0.5^{\circ}$, nRCM-MOD, and OISST. (f) As in (e), but for a zonal section at $26^{\circ} \mathrm{S}$, approximate latitude of Lüderitz.

negative WSC], in other models it does not [the Estimating the Circulation and Climate of the Oceans (ECCO) model, the data-assimilating Massachusetts Institute of Technology GCM: see Figs. 2a,c,e of Thomas et al. (2014), which show northward ocean transport and negative WSC]. In the above cases, HiGEM has a broad WSC structure as seen in CCSM 4 with $1^{\circ}$ or $2^{\circ}$ resolution in the atmosphere; in common with most climate models, it also has a large Benguela SST bias (Shaffrey et al. 2009). In contrast ECCO employs satellite-based winds into its solution so the WSC structure is relatively narrow, thus being more similar to the nRCM-MOD experiment discussed here.

Observations also tell a mixed story about the appropriateness of Sverdrup balance. An analysis of ARGO float data by Gray and Riser (2014) showed that Sverdrup balance provided a poor fit to ocean transport in the region, but their Fig. 1 suggests the region is very data sparse. Meanwhile Lass and Mohrholz (2008) argue that Sverdrup balance is appropriate in the South Atlantic subtropical gyre and eastern boundary. However, regional models tell a more consistent story, with Veitch et al. (2009) and Junker et al. (2015) suggesting an approximate Sverdrup balance holds in the Benguela region, especially in austral summer [December-February (DJF)], when the undercurrent is strong, but less so in austral winter (JJA), the season focused on in this paper, when the undercurrent is relatively weak (see also Muller et al. 2014).

On a smaller scale, the WSC has also been related to gradients of SST, in observations and high-resolution coupled models (Chelton et al. 2007; Perlin et al.2007; Haack et al. 2008; Jin et al. 2009). In the CCSM4 experiments and control nRCM experiments presented in this paper, the absence of an upwelling SST front means that such SST-wind stress couplings are mostly absent near the coast. However, the presence of an upwelling front in nRCM-MOD allows for the possibility of such finescale coupling, and this will be explored in future work, where a suite of simulations with differing shifts of the wind jet have been performed.

\section{b. Response to improved winds with standard ocean resolution}

It may be asked whether the response to the "wind shift" of section 4a would be as strong in a non-eddy-resolving ocean model as in ROMS. This was tested by performing 
(a)

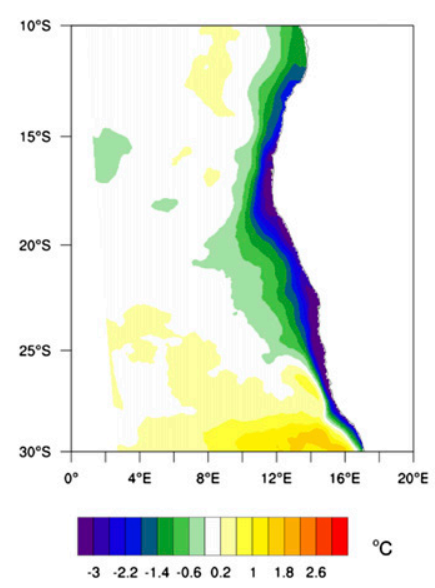

(c)

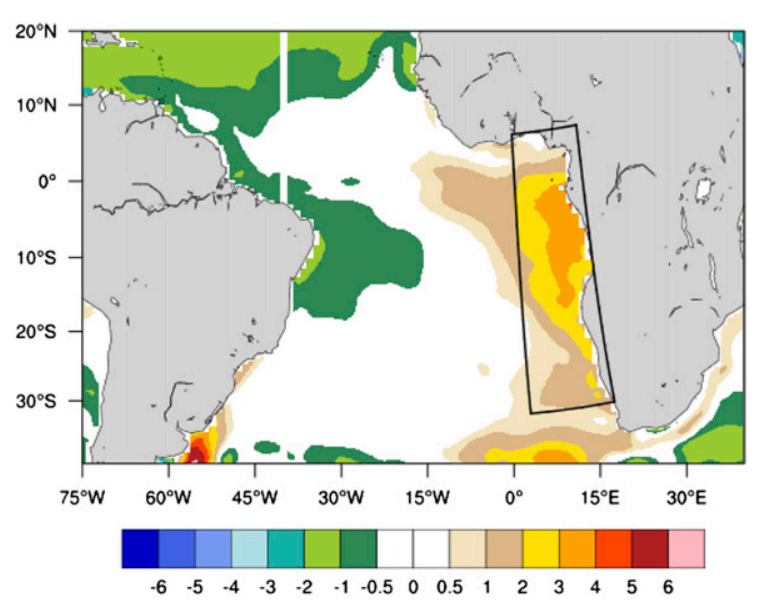

(b)

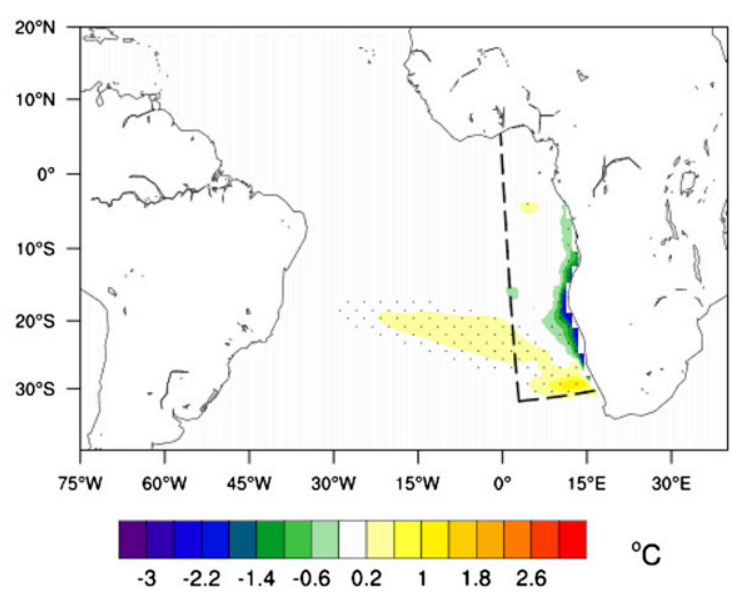

(d)

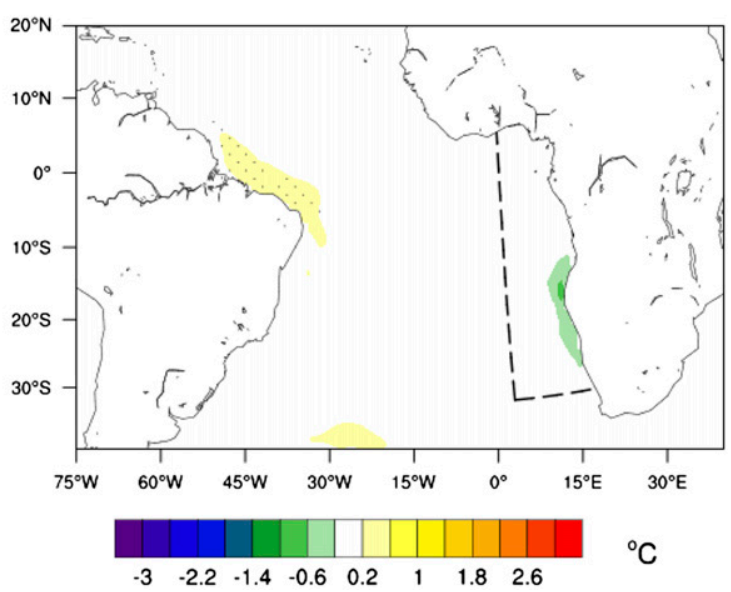

FIG. 16. SST difference for JJA, (a) for the nRCM-MOD experiment, relative to nRCM- $0.5^{\circ}$, data on ROMS grid; (b) as in (a), but on the POP grid and showing a larger Atlantic domain; (c) between nRCM-MOD and HadISST observations, and (d) for the CCSM4-MOD experiment, relative to CCSM4-0.5 .

a similar experiment to $\mathrm{nRCM}-\mathrm{MOD}$, but in CCSM4-0.5 (i.e., by applying the wind shifting to the global $1^{\circ}$ POP ocean model rather than to ROMS). In this experiment (CCSM4-MOD) the offshore jet distance was reduced from $L=2^{\circ}$ to $L=1^{\circ}$ (Table 2), and there was a much reduced WSC (the maximum magnitude of the negative WSC near the coast was reduced to $1.75 \times 10^{-7} \mathrm{~N} \mathrm{~m}^{-3}$ compared to $>3.0 \times 10^{-7} \mathrm{Nm}^{-3}$ in CCSM4-0.5 $)$. However, the SST change at the coast going from CCSM4- $0.5^{\circ}$ to CCSM4-MOD is much more modest than the corresponding $\mathrm{nRCM}$ experiments, and is mostly less than $0.6^{\circ} \mathrm{C}$ in the Benguela zone (Fig. 16d). Further investigation showed that differences in meridional surface current $V$ are $<0.025 \mathrm{~m} \mathrm{~s}^{-1}$ over most of the domain, and vertical velocity differed by less than $0.4 \mathrm{~m} \mathrm{day}^{-1}$, much smaller than the coastal changes seen in $\mathrm{nRCM}-\mathrm{MOD}$.

In general, the horizontal currents and vertical velocity in POP are much weaker than those in ROMS, even when the wind stress applied to POP is quite strong near the coast (i.e., in CCSM4-0.5 $5^{\circ}$ or CCSM4-MOD; see Table 3). Why is this? A commonly used expression for vertical velocity $w$, derived from Ekman balance is $w=\left(\tau_{y} / \rho f \lambda\right)$, where $\tau_{y}$ is the alongshore wind stress and $\rho$ the water density, involves division by a scale $\lambda$ of the upwelling; $\lambda$ is often taken as the Rossby radius (Allen 1973). This radius is typically tens of kilometers in coastal zones, and around $30-40 \mathrm{~km}$ at the latitude of Benguela. Likewise the alongshore current decays away from the coastline on the scale of $\lambda$ (Fennel et al. 2012; Junker 2014). An alternative theoretical definition of $\lambda$ (Estrade et al. 2008) takes into account bottom topography slope $S$, and is given by $\lambda=0.75 D / S$, where $D$ is Ekman depth. Marchesiello and Estrade (2010) estimate scales of upwelling of $\sim 10 \mathrm{~km}$ (inferred from their Fig. 14). These small $O(10) \mathrm{km}$ horizontal scales of motion are partly resolved by the 7-km grid cells of ROMS but are not resolved by the POP grid cells, which are about $100 \mathrm{~km}$ wide in the zonal direction at these latitudes. 
(a)

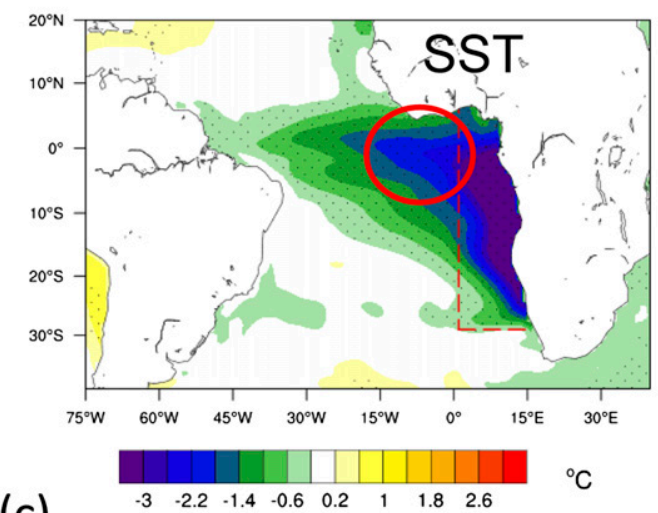

(c)

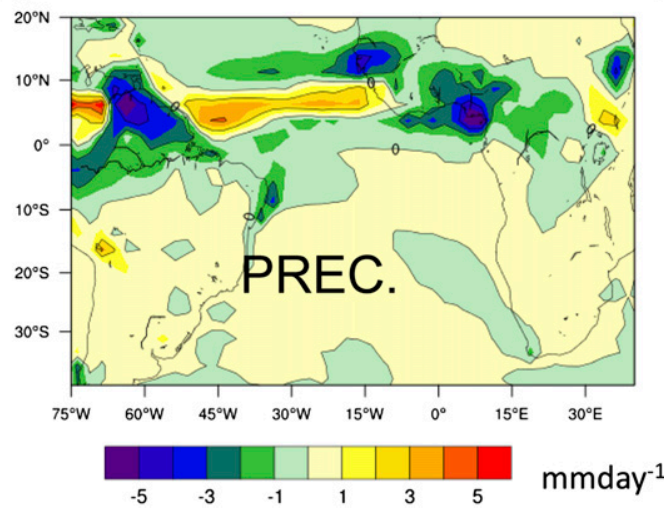

(b)

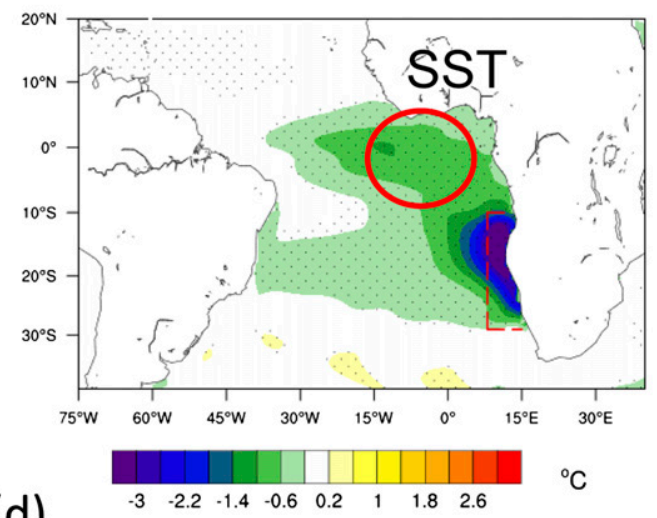

(d)

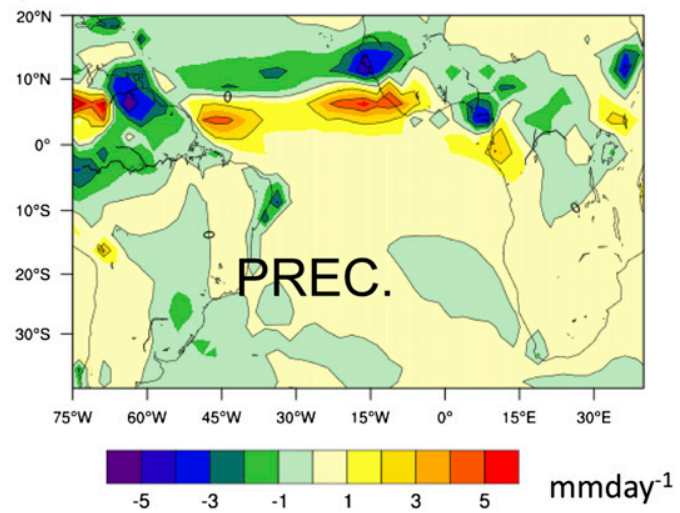

FIG. 17. Remote effect of restoring temperature and salinity in the eastern Atlantic, for (left) the LARGE restoring domain case and (right) the SMALL domain case. (a),(b) SST differences from CCSM4-0.5 ${ }^{\circ}$, for JJA. (c),(d) corresponding precipitation bias relative to GPCP; compare to Fig. 1b. Original bias in circled region is $1^{\circ}-$ $3^{\circ} \mathrm{C}$ (see Fig. 1a). Red dashed lines in (a) and (b) denote the restoring domain.

Note that although the most realistic Benguela system of this study is obtained with the embedded fully nonlinear, eddying ROMS model, much of the improvement in the time-mean state is due to resolving the linear processes discussed in McCreary et al. (1987), Fennel et al. (2012), and Junker (2014)—namely the coastal jet and upwelling, when forced by a reasonable coastal wind stress. [Junker (2014) also shows that his linear box model reproduces many of the seasonal-mean features of a full ROMS simulation.] Of course, the use of highresolution ocean models will also enable better representation of the transient eddy field (and its feedback to the mean flow), not discussed here but treated in full in, for example, Marchesiello et al. (2003), Capet et al. (2008), Veitch et al. (2010), Toniazzo et al. (2010), and Colas et al. (2013).

The sensitivity to coastal wind stress shown in this paper is quite dramatic and consistent with that seen by Capet et al. (2004). However, Richter et al. (2012) and Voldoire et al. (2014) obtained a weaker response when restoring winds to ICOADS and ERA-Interim respectively in the Benguela coastal zone. The reasons for this difference [as discussed in Voldoire et al. (2014)] are likely to be some combination of low model resolution in Richter et al. ( $\sim 2^{\circ}$ atmosphere and $1^{\circ}$ ocean) and Voldoire et al. ( $\sim 1^{\circ}$ ocean-atmosphere), following the arguments of the previous paragraph, and lack of wind detail in the restored wind products and the detailed treatment of the ocean-land wind contrast.

\section{Conclusions}

Eastern boundary SST error in the southeast Atlantic in a global coupled climate model has been investigated by varying the resolution of model components, and by sensitivity studies to coastal wind stress and to restored ocean temperature and salinity. The following conclusions were drawn.

At low atmosphere resolution $\left(2^{\circ}-1^{\circ}\right)$, a Sverdrup balance dominates the ocean response such that southward coastal transport and surface flow is associated with negative WSC and weak coastal winds. The southward 
transport and weak coastal upwelling contributes to the large SST bias. Going from an atmosphere grid spacing of $1^{\circ}-0.5^{\circ}$, there is a strengthening of coastal winds and narrowing of the WSC. There is also a weakening of the fit to Sverdrup dynamics, and an almost $2^{\circ} \mathrm{C}$ reduction of the warm coastal bias occurs, due to a reversal of sign of the coastal flow, from poleward (warm advection) to weak equatorward (cold advection), as well as an increase in upwelling velocities. Despite these improvements to current structure, a $5^{\circ} \mathrm{C} \mathrm{SST} \mathrm{bias} \mathrm{remains.}$ Inclusion of a high-resolution regional ocean model does not improve the coastal solution when the WSC is strong and wide, as in our control nRCM experiments. Again the WSC leads to approximate Sverdrup and Ekman pumping dynamics governing the meridional and vertical velocities respectively.

Modifying the wind applied to the regional ocean model, such that coastal winds are strengthened to more realistic values, led to large changes in surface current structure and upwelling. The dominant coastal currents became equatorward (cold advection), driven by strong coastal winds, and upwelling became much stronger and localized at the coast. Consequently the SST at the coast was reduced, by up to $3^{\circ} \mathrm{C}$, relative to the nRCM control and CCSM4, giving much more realistic SST gradients. In contrast, modifying the wind applied to the standard $1^{\circ}$ resolution ocean model did not give a large response.

All the above results indicate that the focus of future studies and coupled model development should be on improving the WSC in high-resolution atmosphere models, while using an eddy-resolving ocean model.

It was also found that fixing the temperature and salinity bias over a broad offshore region west of Angola/ Namibia, extending $\sim 500 \mathrm{~km}$ or more offshore, gave a substantial remote response in the equatorial Atlantic. However, improving the Benguela coastal currents and upwelling alone (mostly within $\sim 200 \mathrm{~km}$ of the coast), gave a negligible remote response. Despite this lack of remote response, improvements to the Angola/Benguela coastal region do have other important applications. Interannual variability in that region has been shown to be sensitive to the mean state and annual cycle (Ding et al. 2015). Further, more realistic upwelling should improve the biogeochemistry in these region in coupled ocean-biogeochemistry (or complete earth system models like the Community Earth System Model), where large deficiencies in primary productivity have been noted (Moore et al. 2013).

Acknowledgments. I. Richter, T. Toniazzo, and an anonymous reviewer are thanked for their comments, which improved the paper substantially. T. Toniazzo suggested the role of spatial scales governing whether
Sverdrup balance holds. Furthermore, a number of people contributed to this work and are gratefully thanked. P. Chang and M. Schmidt shared relevant results and pointing the authors to the Fennel et al. (2012) paper. F. Desbiolles shared results on analysis of scatterometer data of the Benguela region. C. Shields advised on CCSM4- $0.5^{\circ}$ simulations and provided access to existing data. P. Gent provided valuable comments on drafts of the paper. J. Hurrell was an original motivator and supporter of the nested regional climate model. In addition a large number of people contributed by stimulating discussions on this topic, including R. Mechoso, P. Zuidema, M. Jochum, N. Keenlyside, C. Patricola, F. Castruccio, Z. Xu, E. Muñoz, B. Medeiros, F. Bryan, S. Masson, V. Echevin, F. Colas, M. Alexander, and Z. Powell. We gratefully acknowledge the ROMS developers and user group. This work was funded by NSF Project Award 0961545.

\section{REFERENCES}

Allen, J. S., 1973: Upwelling and coastal jets in a continuously stratified ocean. J. Phys. Oceanogr., 3, 245-257, doi:10.1175/ 1520-0485(1973)003<0245:UACJIA > 2.0.CO;2.

Banzon, V. F., R. W. Reynolds, D. Stokes, and Y. Xue, 2014: A 1/4 spatial-resolution daily sea surface temperature climatology based on a blended satellite and in situ analysis. J. Climate, 27, 8221-8228, doi:10.1175/JCLI-D-14-00293.1.

Capet, X. J., P. Marchesiello, and J. C. McWilliams, 2004: Upwelling response to coastal wind profiles. Geophys. Res. Lett., 31, L13311, doi:10.1029/2004GL020123.

— F. Colas, J. C. Mcwilliams, P. Penven, and P. Marchesiello, 2008: Eddies in eastern boundary subtropical upwelling systems. Ocean Modeling in an Eddying Regime, Geophys. Monogr., Vol. 177, Amer. Geophys. Union, doi:10.1029/ 177GM10.

Charney, J. G., 1955: Generation of oceanic currents by wind. J. Mar. Res., 14, 477-498.

Chelton, D. B., M. G. Schlax, and R. M. Samelson, 2007: Summertime coupling between sea surface temperature and wind stress in the California Current System. J. Phys. Oceanogr., 37, 495-517, doi:10.1175/JPO3025.1.

Colas, F., X. Capet, J. C. McWilliams, and Z. Li, 2013: Mesoscale eddy buoyancy flux and eddy-induced circulation in eastern boundary currents. J. Phys. Oceanogr., 43, 1073-1095, doi:10.1175/JPO-D-11-0241.1.

Colberg, F., and C. J. C. Reason, 2006: A model study of the Angola Benguela frontal zone: Sensitivity to atmospheric forcing. Geophys. Res. Lett., 33, L19608, doi:10.1029/ 2006 GL027463.

Danabasoglu, G., S. C. Bates, B. P. Briegleb, S. R. Jayne, M. Jochum, W. G. Large, S. Peacock, and S. G. Yeager, 2012: The CCSM4 ocean component. J. Climate, 25, 1361-1389, doi:10.1175/JCLI-D-11-00091.1.

Davey, M., and Coauthors, 2002: STOIC: A study of coupled model climatology and variability in tropical ocean regions. Climate Dyn., 18, 403-420, doi:10.1007/s00382-001-0188-6.

Delworth, T. L., and Coauthors, 2012: Simulated climate and climate change in the GFDL CM2.5 high-resolution coupled 
climate model. J. Climate, 25, 2755-2781, doi:10.1175/ JCLI-D-11-00316.1.

Desbiolles, F., B. Blanke, and A. Bentamy, 2014: Short-term upwelling events at the western African coast related to synoptic atmospheric structures as derived from satellite observations. J. Geophys. Res. Oceans, 119, 461-483, doi:10.1002/ 2013JC009278.

Ding, H., N. Keenlyside, M. Latif, W. Park, and S. Wahl, 2015: The impact of mean state errors on equatorial Atlantic interannual variability in a climate model. J. Geophys. Res. Oceans, $\mathbf{1 2 0}$, 1133-1151, doi:10.1002/2014JC010384.

Enriquez, A. G., and C. A. Friehe, 1995: Effects of wind stress and wind stress curl variability on coastal upwelling. J. Phys. Oceanogr., 25, 1651-1671, doi:10.1175/1520-0485(1995)025<1651: EOWSAW $>2.0 . \mathrm{CO} ; 2$

Estrade, P., P. Marchesiello, A. C. de Verdière, and C. Roy, 2008: Cross-shelf extension of coastal upwelling: A two-dimensional extension of Ekman's theory and a mechanism for inner shelf upwelling shut down. J. Mar. Res., 66, 589-616, doi:10.1357/ 002224008787536790.

Fennel, W., 1999: Theory of the Benguela upwelling system. J. Phys. Oceanogr., 29, 177-190, doi:10.1175/1520-0485(1999)029<0177: TOTBUS $>2.0 . \mathrm{CO} ; 2$

— T. Junker, M. Schmidt, and V. Mohrholz, 2012: Response of the Benguela upwelling systems to spatial variations in the wind stress. Cont. Shelf Res., 45, 65-77, doi:10.1016/ j.csr.2012.06.004.

Gent, P. R., S. G. Yeager, R. B. Neale, S. Levis, and D. A. Bailey, 2010: Improvements in a half degree atmosphere/land version of the CCSM. Climate Dyn., 34, 819-833, doi:10.1007/ s00382-009-0614-8.

- , and Coauthors, 2011: The Community Climate System Model version 4. J. Climate, 24, 4973-4991, doi:10.1175/ 2011JCLI4083.1.

Gray, A. R., and S. C. Riser, 2014: A global analysis of Sverdrup balance using absolute geostrophic velocities from Argo. J. Phys. Oceanogr., 44, 1213-1229, doi:10.1175/ JPO-D-12-0206.1.

Grodsky, S. A., J. A. Carton, S. Nigam, and Y. M. Okumura, 2012: Tropical Atlantic biases in CCSM4. J. Climate, 25, 3684-3701, doi:10.1175/JCLI-D-11-00315.1.

Haack, T., D. Chelton, J. Pullen, J. D. Doyle, and M. Schlax, 2008: Summertime influence of SST on surface wind stress off the U.S. West Coast from the U.S. Navy COAMPS model. J. Phys. Oceanogr., 38, 2414-2437, doi:10.1175/2008JPO3870.1.

Huffman, G. J., and Coauthors, 1997: The Global Precipitation Climatology Project (GPCP) combined precipitation dataset. Bull. Amer. Meteor. Soc., 78, 5-20, doi:10.1175/ 1520-0477(1997)078<0005:TGPCPG > 2.0.CO;2.

Hunke, E. C., and W. H. Lipscomb, 2008: CICE: The Los Alamos sea ice model user's manual, version 4. Los Alamos National Laboratory Tech. Rep. LA-CC-06-012, 76 pp.

Hurrell, J. W., J. J. Hack, D. Shea, J. M. Caron, and J. Rosinski, 2008: A new sea surface temperature and sea ice boundary dataset for the Community Atmosphere Model. J. Climate, 21, 5145-5153, doi:10.1175/2008JCLI2292.1.

Jin, X., C. Dong, J. Kurian, J. C. McWilliams, D. B. Chelton, and Z. Li, 2009: SST-wind interaction in coastal upwelling: Oceanic simulation with empirical coupling. J. Phys. Oceanogr., 39, 2957-2970, doi:10.1175/2009JPO4205.1.

Junker, T., 2014: Response of the Benguela upwelling system to changes in the wind forcing. Ph.D. dissertation, University of Rostock and Leibniz-Institut für Ostseeforschung Warnemünde,
99 pp. [Available online at http://www.io-warnemuende.de/ tl_files/staff/tjunker/Junker_2014.pdf.]

- - M. Schmidt, and V. Mohrholz, 2015: The relation of wind stress curl and meridional transport in the Benguela upwelling system. J. Mar. Syst., 143, 1-6, doi:10.1016/ j.jmarsys.2014.10.006.

Kara, A. B., A. J. Wallcraft, and H. E. Hurlbert, 2007: A correction for land contamination of atmospheric variables near land-sea boundaries. J. Phys. Oceanogr., 37, 803-818, doi:10.1175/ JPO2984.1.

Large, W. G., and G. Danabasoglu, 2006: Attribution and impacts of upper-ocean biases in CCSM3. J. Climate, 19, 2325-2346, doi:10.1175/JCLI3740.1.

, and S. G. Yeager, 2009: The global climatology of an interannually varying air-sea flux data set. Climate Dyn., 33, 341364, doi:10.1007/s00382-008-0441-3.

_ J. C. McWilliams, and S. C. Doney, 1994: Oceanic vertical mixing: A review and a model with nonlocal boundary layer parameterization. Rev. Geophys., 32, 363-403, doi:10.1029/ 94RG01872.

Lass, H. U., and V. Mohrholz, 2008: On the interaction between the subtropical gyre and the subtropical cell on the shelf of the SE Atlantic. J. Mar. Syst., 74, 1-43, doi:10.1016/ j.jmarsys.2007.09.008.

Levitus, S., T. Boyer, M. Conkright, D. Johnson, T. O'Brien, J. Antonov, C. Stephens, and R. Gelfeld, 1998: Introduction. Vol. 1, World Ocean Database 1998, NOAA Atlas NESDIS $18,346 \mathrm{pp}$.

Ma, C.-C., C. R. Mechoso, A. W. Robertson, and A. Arakawa, 1996: Peruvian stratus clouds and the tropical Pacific circulation: A coupled ocean-atmosphere GCM study. J. Climate, 9, 1635-1645, doi:10.1175/1520-0442(1996)009<1635: PSCATT $>2.0 . \mathrm{CO} ; 2$.

Marchesiello, P., and P. Estrade, 2010: Upwelling limitation by onshore geostrophic flow. J. Mar. Res., 68, 37-62, doi:10.1357/ 002224010793079004

- J. C. McWilliams, and A. Shchepetkin, 2001: Open boundary conditions for long-term integration of regional oceanic models. Ocean Modell., 3, 1-20, doi:10.1016/ S1463-5003(00)00013-5.

,-- , and -2003 : Equilibrium structure and dynamics of the California Current System. J. Phys. Oceanogr., 33, 753-783, doi:10.1175/1520-0485(2003)33<753: ESADOT $>2.0 . \mathrm{CO} ; 2$

McClean, J. L., and Coauthors, 2011: A prototype two-decade fully-coupled fine resolution CCSM simulation. Ocean Modell., 39, 10-30, doi:10.1016/j.ocemod.2011.02.011.

McCreary, J. P., and S.-Y. Chao, 1985: Three-dimensional shelf circulation along an eastern ocean basin. J. Mar. Res., 43, 1336, doi:10.1357/002224085788437316.

—, P. K. Kundu, and S.-Y. Chao, 1987: On the dynamics of the California Current System. J. Mar. Res., 45, 1-32, doi:10.1357/ 002224087788400945.

Mechoso, C. R., and Coauthors, 1995: The seasonal cycle over the tropical Pacific in coupled ocean-atmosphere general circulation models. Mon. Wea. Rev., 123, 2825-2838, doi:10.1175/ 1520-0493(1995)123<2825:TSCOTT $>2.0$. CO;2.

, and Coauthors, 2014: Ocean-cloud-atmosphere-land interactions in the southeastern Pacific: The VOCALS program. Bull. Amer. Meteor. Soc., 95, 357-375, doi:10.1175/ BAMS-D-11-00246.1.

Meehl, G. A., P. R. Gent, J. M. Arblaster, B. L. Otto-Bleisner, E. C. Brady, and A. Craig, 2001: Factors that affect the amplitude of 
El Niño in global coupled models. Climate Dyn., 17, 515-526, doi:10.1007/PL00007929.

Moore, J. K., K. Lindsay, S. C. Doney, M. C. Long, and K. Misumi, 2013: Marine Ecosystem Dynamics and Biogeochemical Cycling in the Community Earth System Model [CESM1(BGC)]: Comparison of the 1990s with the 2090s under the RCP4.5 and RCP8.5 scenarios. J. Climate, 26, 9291-9312, doi:10.1175/ JCLI-D-12-00566.1.

Muller, A. A., C. J. C. Reason, M. Schmidt, V. Mohrholz, and A. Eggert, 2014: Computing transport budgets along the shelf and across the shelf-edge in the northern Benguela during summer (DJF) and winter (JJA). J. Mar. Syst., 140, 82-91, doi:10.1016/j.jmarsys.2014.02.007.

Neale, R. B., J. Richter, S. Park, P. H. Lauritzen, S. J. Vavrus, P. J. Rasch, and M. Zhang, 2013: The mean climate of the Community Atmosphere Model (CAM4) in forced SST and fully coupled experiments. J. Climate, 26, 5150-5168, doi:10.1175/ JCLI-D-12-00236.1.

Nicholson, S. E., 2010: A low-level jet along the Benguela coast, an integral part of the Benguela current ecosystem. Climatic Change, 99, 613-624, doi:10.1007/s10584-009-9678-z.

Oleson, K. W., and Coauthors, 2008: Improvements to the Community Land Model and their impact on the hydrological cycle. J. Geophys. Res., 113, G01021, doi:10.1029/ 2007JG000563.

Penven, P., V. Echevin, J. Pasapera, F. Colas, and J. Tam, 2005: Average circulation, seasonal cycle, and mesoscale dynamics of the Peru Current System: A modeling approach. J. Geophys. Res., 110, C10021, doi:10.1029/2005JC002945.

Perlin, N. P., E. D. Skyllingstad, R. M. Samelson, and P. L. Barbour, 2007: Numerical simulation of air-sea coupling during coastal upwelling. J. Phys. Oceanogr., 37, 2081-2093, doi:10.1175/JPO3104.1.

Philander, S. G. H., and J.-H. Yoon, 1982: Eastern boundary currents and coastal upwelling. J. Phys. Oceanogr., 12, 862-879, doi:10.1175/1520-0485(1982)012<0862:EBCACU>2.0.CO;2.

Pickett, M. H., and J. D. Paduan, 2003: Ekman transport and pumping in the California Current based on the U.S. Navy's high-resolution atmospheric model (COAMPS). J. Geophys. Res., 108, 3327, doi:10.1029/2003JC001902.

Renault, L., and Coauthors, 2012: Upwelling response to atmospheric coastal jets off central Chile: A modeling study of the October 2000 event. J. Geophys. Res., 117, C02030, doi:10.1029/2011JC007446.

Reynolds, R. W., T. M. Smith, C. Liu, D. B. Chelton, K. S. Casey, and M. G. Schlax, 2007: Daily high-resolution-blended analyses for sea surface temperature. J. Climate, 20, 5473-5496, doi:10.1175/2007JCLI1824.1.

Richter, I., 2015: Climate model biases in the eastern tropical oceans: Causes, impacts and ways forward. Wiley Interdiscip. Rev. Climate Change, 6, 345-358, doi:10.1002/wcc.338.

- and S.-P. Xie, 2008: On the origin of equatorial Atlantic biases in coupled general circulation models. Climate Dyn., 31, 587-598, doi:10.1007/s00382-008-0364-z.

,,-- A. Wittenberg, and Y. Masumoto, 2012: Tropical Atlantic biases and their relationship to surface wind stress and terrestrial precipitation. Climate Dyn., 38, 985-1001, doi:10.1007/ s00382-011-1038-9.

, - - S. K. Behera, T. Doi, and Y. Masumoto, 2014: Equatorial Atlantic variability and its relation to mean state biases in CMIP5. Climate Dyn., 42, 171-188, doi:10.1007/s00382-012-1624-5.
Risien, C. M., and D. B. Chelton, 2008: A global climatology of surface wind and wind stress fields from eight years of QuikSCAT scatterometer data. J. Phys. Oceanogr., 38, 23792413, doi:10.1175/2008JPO3881.1.

Shaffrey, L. C., and Coauthors, 2009: U.K. HiGEM: The new U.K. high-resolution global environment model-Model description and basic evaluation. J. Climate, 22, 1861-1896, doi:10.1175/ 2008JCLI2508.1.

Shchepetkin, A. F., and J. C. McWilliams, 2005: The Regional Ocean Modeling System (ROMS): A split-explicit, free-surface, topography-following-coordinate oceanic model. Ocean Modell., 9, 347-404, doi:10.1016/j.ocemod.2004.08.002.

Smith, R. D., and Coauthors, 2010: The Parallel Ocean Program (POP) reference manual. Los Alamos National Laboratory Tech. Rep. LAUR-10-01853, 140 pp.

Song, H., A. J. Miller, B. D. Cornuelle, and E. Di Lorenzo, 2011: Changes in upwelling and its water sources in the California Current System driven by different wind forcing. Dyn. Atmos. Oceans, 52, 170-191, doi:10.1016/j.dynatmoce.2011.03.001.

Thomas, M. D., A. M. De Boer, H. L. Johnson, and D. P. Stevens, 2014: Spatial and temporal scales of Sverdrup balance. J. Phys. Oceanogr., 44, 2644-2660, doi:10.1175/JPO-D-13-0192.1.

Toniazzo, T., 2010: Climate variability in the south-east Pacific and its relation with ENSO: A GCM study. Climate Dyn., 34, 1093-1114, doi:10.1007/s00382-009-0602-z.

_- , and S. Woolnough, 2014: Development of warm SST errors in the southern tropical Atlantic in CMIP5 decadal hindcasts. Climate Dyn., 43, 2889-2913, doi:10.1007/ s00382-013-1691-2.

_ C. R. Mechoso, L. C. Shaffrey, and J. M. Slingo, 2010: Upperocean heat budget and ocean eddy transport in the southeast Pacific in a high-resolution coupled model. Climate Dyn., 35, 1309-1329, doi:10.1007/s00382-009-0703-8.

Veitch, J., P. Penven, and F. Shillington, 2009: The Benguela: A laboratory for comparative modeling studies. Prog. Oceanogr., 83, 296-302, doi:10.1016/j.pocean.2009.07.008.

,-- , and — 2010: Modelling equilibrium dynamics of the Benguela Current System. J. Phys. Oceanogr., 40, 1942-1964, doi:10.1175/2010JPO4382.1.

Voldoire, A., M. Claudon, G. Caniaux, H. Giordani, and R. Roehrig, 2014: Are atmospheric biases responsible for tropical Atlantic SST biases in the CNRM-CM5 model? Climate Dyn., 43, 2963-2984, doi:10.1007/s00382-013-2036-x.

Wahl, S., M. Latif, W. Park, and N. Keenlyside, 2011: On the tropical Atlantic SST warm bias in the Kiel Climate Model. Climate Dyn., 36, 891-906, doi:10.1007/s00382-009-0690-9.

Wang, C., L. Zhang, S.-K. Lee, L. Wu, and C. R. Mechoso, 2014: A global perspective on CMIP5 climate model biases. Nat. Climate Change, 4, 201-205, doi:10.1038/nclimate2118.

Wunsch, C., 2011: The decadal mean circulation and Sverdrup balance. J. Mar. Res., 69, 417-434, doi:10.1357/002224011798765303.

Xu, Z., P. Chang, I. Richter, W. Kim, and G. Tang, 2014a: Diagnosing southeast tropical Atlantic SST and ocean circulation biases in the CMIP5 ensemble. Climate Dyn., 43, 3123-3145, doi:10.1007/s00382-014-2247-9.

_ M. Li, C. M. Patricola, and P. Chang, 2014b: Oceanic origin of southeast tropical Atlantic biases. Climate Dyn., 43, 29152930, doi:10.1007/s00382-013-1901-y.

Yoshida, K., 1955: Coastal upwelling off the California coast. Rec. Oceanogr. Works Japan, 2 (2), 1-13. 